Delft University of Technology

\title{
First Tests on the Symmetrical Breakwater Armor Unit Crablock
}

\author{
Salauddin, M; Broere, A.; Van Der Meer, J. W.; Verhagen, H. J.; Bijl, E
}

DOI

10.1142/S0578563417500206

Publication date

2017

Document Version

Accepted author manuscript

Published in

Coastal Engineering Journal

\section{Citation (APA)}

Salauddin, M., Broere, A., Van Der Meer, J. W., Verhagen, H. J., \& Bijl, E. (2017). First Tests on the Symmetrical Breakwater Armor Unit Crablock. Coastal Engineering Journal, 59(4), [1750020]. https://doi.org/10.1142/S0578563417500206

\section{Important note}

To cite this publication, please use the final published version (if applicable).

Please check the document version above.

\section{Copyright}

Other than for strictly personal use, it is not permitted to download, forward or distribute the text or part of it, without the consent of the author(s) and/or copyright holder(s), unless the work is under an open content license such as Creative Commons.

\section{Takedown policy}

Please contact us and provide details if you believe this document breaches copyrights.

We will remove access to the work immediately and investigate your claim. 
First tests on the symmetrical breakwater armour unit Crablock

\author{
M. Salauddin ${ }^{1,2^{*}}$, A. Broere ${ }^{3}$, J.W. Van der Meer ${ }^{4}$, H. J. Verhagen ${ }^{5}$ and E. Bijl ${ }^{6}$ \\ ${ }^{1}$ Department of Civil Engineering, Chittagong University of Engineering and Technology, \\ Chittagong-4349, Bangladesh; email: mdsalauddin24@gmail.com \\ ${ }^{2}$ MSc-student IHE Delft, Delft, The Netherlands \\ ${ }^{3}$ MSc-student Delft University of Technology, The Netherlands \\ ${ }^{4}$ IHE Delft, Delft, The Netherlands \\ ${ }^{5}$ Delft University of Technology, Delft, The Netherlands \\ ${ }^{6}$ CDR International, Rijssen, The Netherlands
}

\begin{abstract}
Single layer concrete armour systems are being widely used nowadays in the design of rubble mound breakwaters. Recently, a new concrete armour unit has been developed and applied as single layer armour system in the repair works of one damaged breakwater at Al Fujeirah, UAE. It has a symmetrical shape, in contrast to most other units. Modern single layer concrete armour units that exist at this moment have design guidelines in terms of placement, stability and overtopping. However, because of lack of laboratory research and the little experience of using Crablock, no design guidance exists yet for this new single layer block compared to other existing one layer units. Being a new armour unit, the placement was investigated first. Then physical model tests were performed in a wave flume to come up with results on stability and wave overtopping. Furthermore, to determine the interlocking properties of armour units, pull tests were also conducted in this research. The placement tests showed that uniform placement was best achieved with a rectangular grid on a relatively small underlayer of rock. Test results on stability showed that longer waves affected the armour layer a little more, with more rocking and earlier start of damage. Packing density as well as placement pattern showed no influence on wave overtopping. The overtopping tests gave larger overtopping than expected, which might be due to the fairly steep 1:30 foreshore that gave a large ratio of significant wave height from the time domain and the spectral wave height.
\end{abstract}

KEYWORDS: Crablock; placement pattern; single layer armour; stability; wave overtopping.

\title{
1. INTRODUCTION
}

Generally, coastal structures such as breakwaters are applied for harbours and as similar structures along coasts to protect beaches from the action of waves and currents and to stop siltation in approach channels. Rubble mound breakwaters have often been applied by designers, usually made of rock or concrete armour in double layer systems or in one layer systems. Single layer systems using concrete armour units are being widely used nowadays in the design of coastal protections compared to traditional double layer methods.

A new and symmetrical single layer armour unit, the Crablock, has been designed in the UAE. One breakwater was reconstructed with Crablock after experiencing damage, but very limited testing had been performed. After this application, the unit was improved substantially, leading 
to the shape as given in Figure 1 and dimensions (prototype) as presented in Table 1. The Crablock unit consists of six symmetrical truncated cones (legs), one for each face of a hypothetical central cube. The geometry of Crablock demonstrates symmetry in the three directions of the development of the block. At present, standard prototype dimensions range from 2.5 ton to 25 ton, see Hendrikse and Heijboer (2014).

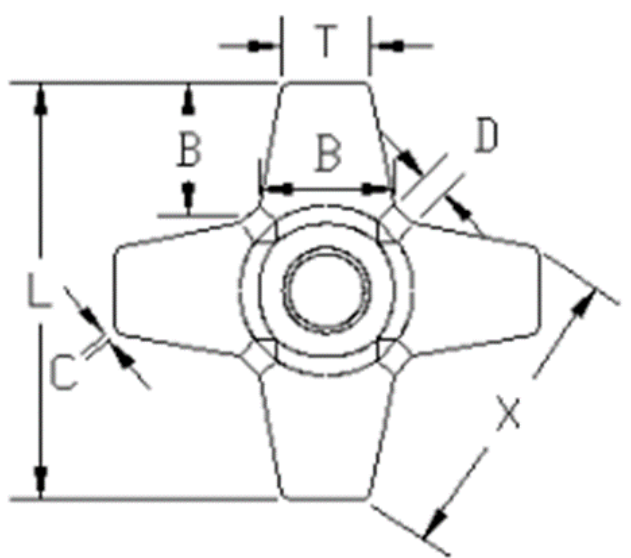

Top view of Crablock

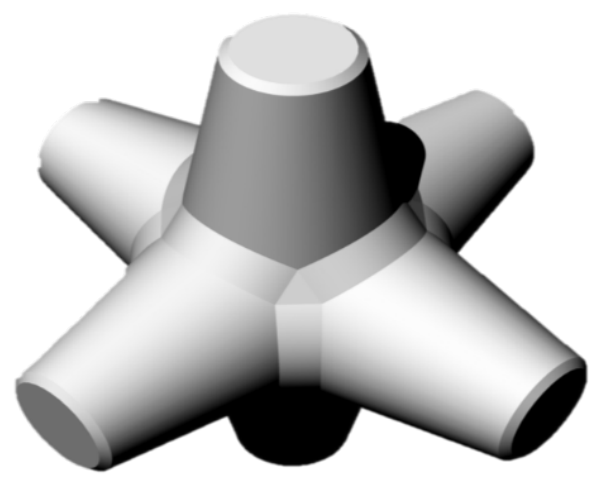

Isometric view of Crablock

Figure 1: Crablock: a new single layer concrete armour unit

Table 1: Dimensions of proposed Crablock unit (Prototype)

\begin{tabular}{|c|c|c|c|c|c|c|c|c|c|}
\hline \multirow{2}{*}{ MODEL } & $\begin{array}{c}\text { UNIT } \\
\text { SPAN } \\
(\mathrm{mm})\end{array}$ & $\begin{array}{c}\text { ARM'S } \\
\text { BASE DIA } \\
(\mathrm{mm})\end{array}$ & $\begin{array}{c}\text { ARM'S } \\
\text { TIP DIA } \\
(\mathrm{mm})\end{array}$ & $\begin{array}{c}\text { ARM'S } \\
\text { LENGTH } \\
(\mathrm{mm})\end{array}$ & $\begin{array}{c}\text { TIP'S } \\
\text { CHAMFE } \\
\text { R(mm) }\end{array}$ & $\begin{array}{c}\text { BASE'S } \\
\text { CHAMFE } \\
\text { R(mm) }\end{array}$ & $\begin{array}{c}\text { X SPAN } \\
(\mathrm{mm})\end{array}$ & $\begin{array}{c}\text { VOLUME } \\
(\text { cu.m) }\end{array}$ & $\begin{array}{c}\text { WEIGHT } \\
\text { (tons) }\end{array}$ \\
\hline CB100 & 1880 & 599 & 385 & 599 & 34 & 115 & 1570 & 1.0 & 2.5 \\
\hline CB200 & 2366 & 754 & 484 & 754 & 43 & 145 & 1977 & 2.0 & 5.0 \\
\hline CB300 & 2712 & 865 & 555 & 865 & 49 & 166 & 2256 & 3.0 & 7.5 \\
\hline CB400 & 2980 & 950 & 610 & 950 & 54 & 183 & 2479 & 4.0 & 10.0 \\
\hline CB500 & 3211 & 1024 & 657 & 1024 & 58 & 197 & 2671 & 5.0 & 12.5 \\
\hline CB600 & 3413 & 1088 & 698 & 1088 & 62 & 209 & 2839 & 6.0 & 15.0 \\
\hline CB700 & 3595 & 1146 & 735 & 1146 & 65 & 220 & 2991 & 7.0 & 17.5 \\
\hline CB800 & 3756 & 1198 & 769 & 1198 & 68 & 230 & 3125 & 8.0 & 20.0 \\
\hline CB900 & 3907 & 1246 & 799 & 1246 & 71 & 239 & 3251 & 9.0 & 22.5 \\
\hline CB1000 & 4049 & 1291 & 828 & 1291 & 73 & 248 & 3369 & 10.0 & 25.0 \\
\hline
\end{tabular}

Single layer concrete armour units that exist at this moment have design guidelines in terms of placement, stability and overtopping. However, because of lack of laboratory research and the little experience of using Crablock, no design guidance exists yet for this new single layer block compared to other existing one layer units. To design a breakwater with Crablock as one layer system, preliminary guidance on placement of Crablock, stability and wave overtopping is required. This led to the present investigation which was performed at Delft University of 
Technology in cooperation with IHE DELFT. It has been described in two MSc-theses, Salauddin (2015) and Broere (2015), which forms the basis of this paper.

It is worth mentioning that the symmetrical shape of Crablock makes the unit different from other existing randomly placed single layer units. Therefore, the placement of Crablock armour units is also assumed different compared to other single layer blocks. As the symmetrical shape was a new item, the placement of this unit was investigated first. After the placement tests, physical model tests were performed in a wave flume to come up with stability and wave overtopping results. Furthermore, to determine the interlocking properties of armour units, pull tests were also conducted in this research.

It should be noted that the status of any patent on the Crablock is unclear. There is no worldwide patent, but there might be copy rights in Qatar, Saudi Arabia, UAE, Oman, Bahrain and Kuwait.

\section{HISTORY OF MODERN SINGLE LAYER ARMOUR UNITS}

The 1950s saw an upsurge interest in developing and using concrete armour for rubble mound breakwaters. Consequently, after the 1950s a large variety of concrete armour units has been invented by various consultants in different countries. As the theme of this research is based on modern single layer concrete armour units, only monolayer systems are discussed in this paper that developed after the failures of the large breakwaters like Sines and Arzeu and that were developed to have very strong interlocking. This first development was the Accropode. The older one layer concrete armour units have been developed as both pattern placed block and randomly oriented blocks, like for example, Cobs, Seabees, Dolos (but mostly applied in two layers), Sheds, Stabits, Hexalegs, Quadripods and others. They will not be treated here.

In the eighties Sogreah introduced first the randomly placed one layer concrete armour unit, which is known as Accropode (CLI, 2011a). After the introduction of Accropode, it has been applied on more than 200 breakwaters (CLI, 2011b).

Next to Accropode in the mid 1990s, another randomly oriented one layer concrete armour unit was invented by U.S. Army corps of Engineers (CLI, 2012), the Core-loc. Melby and Turk, (1994) argued that Core-loc provides a higher stability with good interlocking and a low cost solution compared to other existing irregularly oriented armour units. However, the Rock Manual, (2007) warned that although in comparison to Accropode the hydraulic stability of Core-loc armour unit looks superior, the structural integrity of Core-loc might be lower than the Accropode armour block.

The development of single layer armour units was then followed by the invention of other randomly oriented one layer units, the A-Jack in 1998 by Armortec (although designed as river bank protection), Xbloc in 2003 by Delta Marine Consultants, Accropode II in 2004 by Sogreah, again followed by the Core-loc II in 2006 (Rock Manual, 2007).

Furthermore, in 2005 the Cubipod was developed as one layer with randomly placed units to improve the low hydraulic stability of Cubes, with keeping advantages of high structural strength and easy placement (Gomez-Martin and Medina, 2006). 
Recently, the new concrete armour unit Crablock has been invented in UAE and applied as repair in one damaged rubble mound breakwater as monolayer system.

The main reasons behind the popularity of single layer systems are its characteristics like high interlocking, large structural and hydraulic stability and cost efficiency. Van der Meer (1999) investigated that due to high interlocking properties monolayer armour units can better sustain under higher wave heights compared to conventional double layer armour units. In addition to the stability of structures, a randomly placed one layer armour system provides a better economic solution compared to conventional double layer system by a smaller concrete consumption (Bakker et al., 2003, Muttray et al., 2003, Van Gent et al., 1999). Furthermore, maintenance in a conventional double layer system may be expected if the design storm is exceeded. One layer systems do not show damage for events exceeding the design conditions and are therefore less vulnerable for maintenance (Muttray and Reedijk, 2009).

Failure of one layer systems show a brittle behaviour in contrast to double layer systems (Van der Meer, 1999, Besley and Denechere, 2009, Rock Manual, 2007, Medina and Gómez-Martín, 2012,). This means that the structure is stable to a very high wave height, but fails quite drastically if a certain wave height is exceeded. For this reason a safety factor is required between "start of damage" and the design value. The effect is then that wave heights exceeding the design value still do not show damage, in contrast to double layer systems where a damage curve shows the damage development (Van der Meer, 1999). But it is very important to establish a correct design value with a safety factor that is large enough. There is of course a tension between a commercially attractive safety factor (a unit with a high design value) and the real safety of the structure, (Jensen, 2013). Furthermore, the use of one layer armour systems might increase the rate of overtopping discharge (Bruce, et al., 2009, EurOtop, 2007). Van Gent et al. (1999) mention that various factors like placement pattern, allowable levels of damage and failure systems of armour layers should be treated with care for the application of monolayer systems.

Therefore, it is necessary to understand the behaviour of one layer systems in order to use this system properly in the design of rubble mound breakwaters.

\section{TECHNICAL BACKGROUND}

\subsection{Placement Pattern and Packing Density}

Placement of single layer concrete armour units is difficult and challenging. Moreover, the accuracy and speed of the placement might be affected by harsh conditions during construction and by deep water (Muttray and Reedijk, 2009). However, to ensure a firm armour cover with good interlocking capacity the placement of armour blocks has to be precise (Oever, 2006). The good placement of armour units ensures the stability of single layer armour systems (Muttray, et al., 2005). In addition to hydraulic stability of armour layers, the structural integrity of armour units is also influenced by the placement of single layer armour blocks (Muttray, et al., 2005). To construct a good interlocked armour layer with high hydraulic stability, significant concentration should be paid to the placement of concrete elements. Initial factors governing the placement of 
Crablock can be determined from a theoretical study, Bonfantini (2014). This author proposed a first outline for the placement grid of Crablock, being the start of the present research.

Generally, the placement of armour units with random orientation is relatively easier under water compared to strict orientation of units with uniform placement. Nevertheless, it should be noted that some blocks (such as Accropode) get their high interlocking by random placement and it is difficult to place them in a regular pattern. The regular placement of armour blocks is aesthetically attractive and symmetrical blocks, like Crablock, might be more stable in comparison to random oriented placement. A regular placement on a horizontal plate (just to give two different systems) is shown in Figure 2. Phelp, et al. (2012) argued that Crablock armour units with uniform orientations provide compact interlocking between the units. Hendrikse and Heijboer (2014) believed that Crablock armour units can be placed with uniform orientation in both rectangular and diamond shaped grid, see Figure 2.

Small scale dry placement tests were carried out at the Fluid Mechanics Laboratory of the Faculty of Civil Engineering and Geosciences at Delft University of Technology, Netherlands in cooperation with IHE DELFT. The tests were executed with the use of small units.

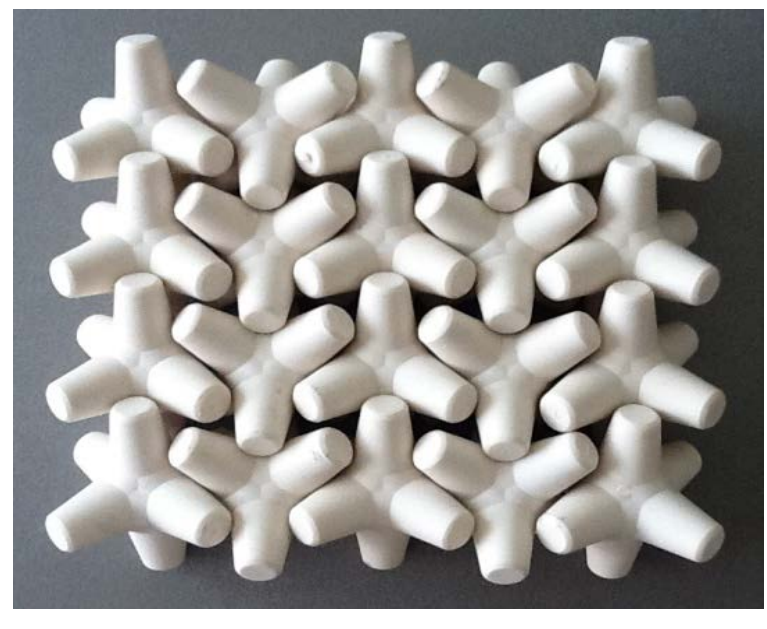

Rectangular grid

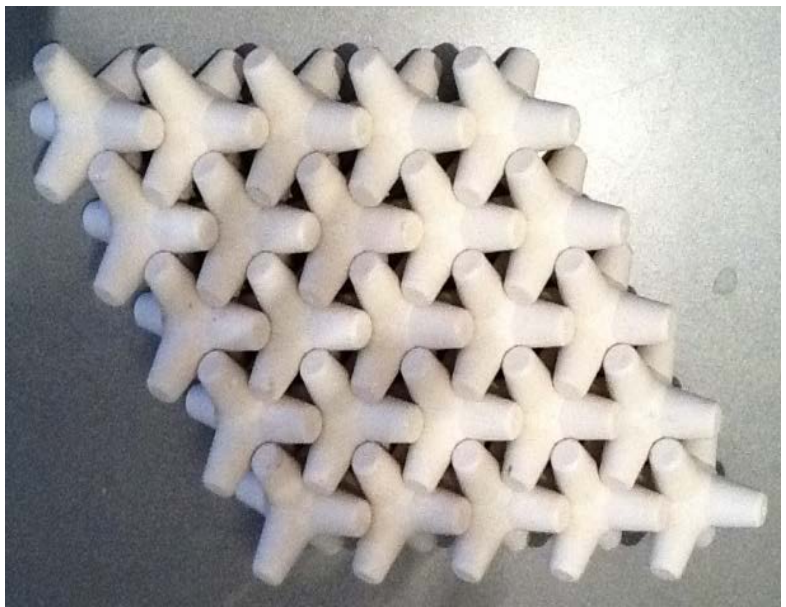

Diamond -Shaped grid

Figure 2: Uniform placement of Crablock [Source: Hendrikse and Heijboer (2014)]. Note that the units have been placed on a horizontal wooden plate, not on a breakwater slope.

\subsection{Stability and Wave Overtopping}

\subsubsection{Stability}

The stability of a breakwater structure is a function between the forcing of the waves and the strength of the structure following from the geometry. The strength of a breakwater armour layer is provided by an interaction between gravity, interlocking, inter-block friction and bottom friction with the underlayer. The contribution of these four mechanisms depends on the shape of the unit, the placement method and packing density. The stability number is usually used to indicate the stability of concrete armour units, which is $\mathrm{H}_{\mathrm{sD}} / \Delta \mathrm{D}_{\mathrm{n}}$, where $\mathrm{H}_{\mathrm{sD}}$ = the design wave height, $\Delta=$ the relative mass density under water and $D_{n}=$ the nominal diameter. 


\section{Damage Definition}

The stability is related to the starting point of damage and the point of failure. To define damage for rubble mound armour several methods have been used. The most obvious method is based on the extraction of units from the armour layer. The number of units displaced from the structure (extractions) can be expressed as a relative strip displacement. The relative strip displacement $\mathrm{N}_{\mathrm{od}}$, is defined as the number of units displaced within a strip of one $\mathrm{D}_{\mathrm{n}}$ width, see equation 1 .

$$
\mathrm{N}_{\mathrm{od}}=n_{d} /\left(B * D_{n}\right)
$$

Where, $\mathrm{N}_{\mathrm{d}}$ is the number of displaced units from the armour layer, $\mathrm{B}$ is the width of breakwater section and $\mathrm{D}_{\mathrm{n}}$ is the diameter of the unit.

When settlement and/or movements become too large, the interlocking function between the units can be lost. A damage criterion based on settlement and movements within the armour layer is therefore introduced in the form of a relative settlement method. A threshold level of movement needs to be defined to quantify the exceeding number of units $N_{\text {om }}$ and is presented in equation 2.

$$
\mathrm{N}_{\mathrm{om}}=n_{m} /\left(B * D_{n}\right)
$$

Where, $\mathrm{N}_{\mathrm{m}}$ is the number of units that moved or settled exceeding threshold level.

Although the structural strength of the units cannot be determined from the physical model tests, repeated movements of the units was visually observed and counted. This typical rotational movements are called "rocking". In reality, rocking can harm the individual units and may lead to damage of the armour layer. Therefore, also a damage criterion for rocking of Crablock units is shown in equation 3.

$$
\mathrm{N}_{\mathrm{or}}=n_{r} /\left(B * D_{n}\right)
$$

Where, $\mathrm{N}_{\mathrm{r}}$ is the number of units that rocked.

\subsubsection{Wave Overtopping}

Sea defences to protect coastal flooding, coastal protections to minimize coastal erosion and breakwaters at harbours to ensure safe navigation and mooring of vessels, are often armoured with single layer units. Design for allowable overtopping of waves is considered as one of the prime concerns (EurOtop, 2007). Overtopping of waves mainly occurs due to the low crest height in comparison to wave run-up levels of the largest waves (TAW, 2002). In that case the crest freeboard $\left(R_{c}\right)$ is calculated by the difference in elevation between height of the crest and the still water level. In general, wave overtopping is expressed by the term mean overtopping discharge per linear metre of width, q, in terms of $\mathrm{m}^{3}$ /s per $\mathrm{m}$ or in l/s per m (EurOtop, 2007).

To be able to use Crablock as a single-layer system on rubble mound breakwaters, preliminary design guidance is also required on wave overtopping over the structure. A limited set of physical model tests was performed on this new armour block by CSIR (2009) in South Africa. However, the wave overtopping discharge Crablock was not measured during those tests. To come up with design guidance on wave overtopping over Crablock slopes, 2D wave flume tests 
were performed in a wave flume at the Fluid Mechanics Laboratory of Delft University of Technology, Netherlands.

\section{Empirical Prediction}

The general formula (equation 4) used for the estimation of wave overtopping discharge over a coastal structure is (EurOtop, 2007),

$$
\frac{q}{\sqrt{\mathrm{gH}_{\mathrm{m} 0}^{3}}}=a \exp \left(-b \frac{R_{c}}{\mathrm{H}_{\mathrm{m} 0}}\right)
$$

EurOtop (2007) describes empirical equations in detail for the approximation of overtopping over rubble mound slopes. The formulae used in this research are only discussed shortly here. Recently, Van der Meer and Bruce (2014) concluded that empirical formulae provided by EurOtop (2007), for breaking waves as well as for non-breaking waves over-estimate wave overtopping for sloping structures with very low or zero crest height. Furthermore, Van der Meer and Bruce (2014) recommended the following formulae (equation 5 and 6) to predict wave overtopping on slopping structures with zero and positive crest height.

- for breaking waves

$$
\frac{q}{\sqrt{\mathrm{gH}_{\mathrm{m} 0}^{3}}}=\frac{0.023}{\sqrt{\tan \alpha}} \cdot \gamma_{\mathrm{b}} \cdot \xi_{\mathrm{m}-1,0} \cdot \exp \left[-\left(2.7 \frac{R_{c}}{\xi_{\mathrm{m}-1,0} \cdot \mathrm{H}_{\mathrm{m} 0} \cdot \gamma_{\mathrm{b}} \cdot \gamma_{\mathrm{f}} \cdot \gamma_{\beta} \cdot \gamma_{\mathrm{v}}}\right)^{1.3}\right]
$$

— and for non-breaking waves a maximum value of

$$
\frac{q}{\sqrt{\mathrm{gH}_{\mathrm{m} 0}^{3}}}=0.09 \cdot \exp \left[-\left(1.5 \frac{R_{c}}{\mathrm{H}_{\mathrm{m} 0} \cdot \gamma_{\mathrm{f}} \cdot \gamma_{\beta}}\right)^{1.3}\right]
$$

The term breaking or non-breaking waves relate to the behaviour of the waves on the structure slope. Breaking waves are plunging waves and non-breaking waves surge up and down the slope without breaking. Waves at the transition from plunging to surging are called collapsing waves, see also EurOtop (2007). In reality, waves may also break over the foreshore due to depth limitations. These are often spilling breakers, unless the foreshore is quite steep. Spilling breakers may reach a structure and may then still be quantified as breaking or non-breaking on the structure slope.

\section{PLACEMENT TESTS OF CRABLOCKS}

\subsection{Test Set-Up}

To perform small scale dry placement tests a model breakwater was constructed with the use of a rock underlayer, a wooden toe and on a wooden frame. The slope of Crablock armour (wooden frame) has been kept as 1:4/3, similar to Accropode, core-loc and Xbloc in their initial model testing to define design parameters. All the placement tests were carried out with the use of small scale Crablock units in average $0.0637 \mathrm{~kg}$ in mass, with $2364 \mathrm{~kg} / \mathrm{m}^{3}$ as mass density and with a nominal diameter of exactly $0.030 \mathrm{~m}$. Two different sizes of underlayer were used to perform the 
placement tests. Initially an underlayer of one-tenth of Crablock armour units (0.003-0.009 kg) has been used. But with the use of this relatively large underlayer, a uniform placement of Crablock was hardly reachable. Thus, to get the uniform placement a relatively smaller underlayer (0.001-0.004 kg) was used to place the armour units, which is about $1 / 25^{\text {th }}$ of the Crablock weight. Figure 3 gives examples of the test set-up followed for performing the dry placement tests.

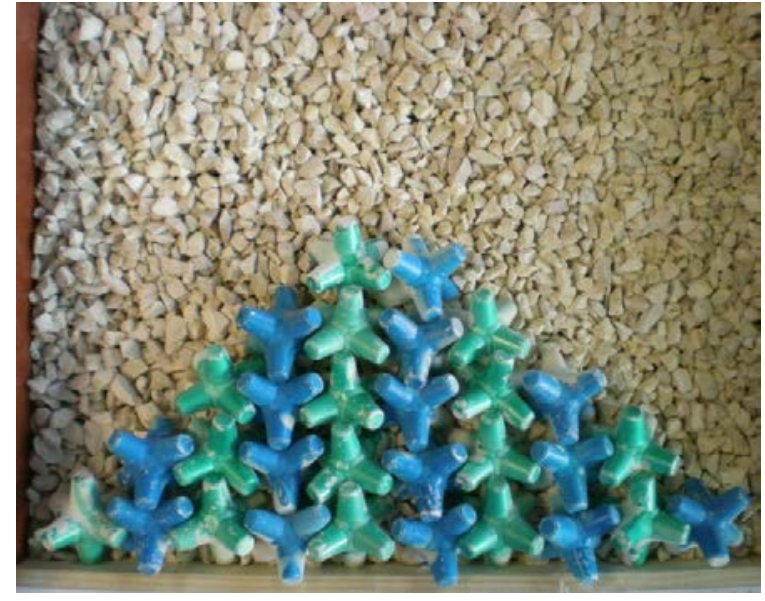

Uniform placement using smaller underlayer in a rectangular grid

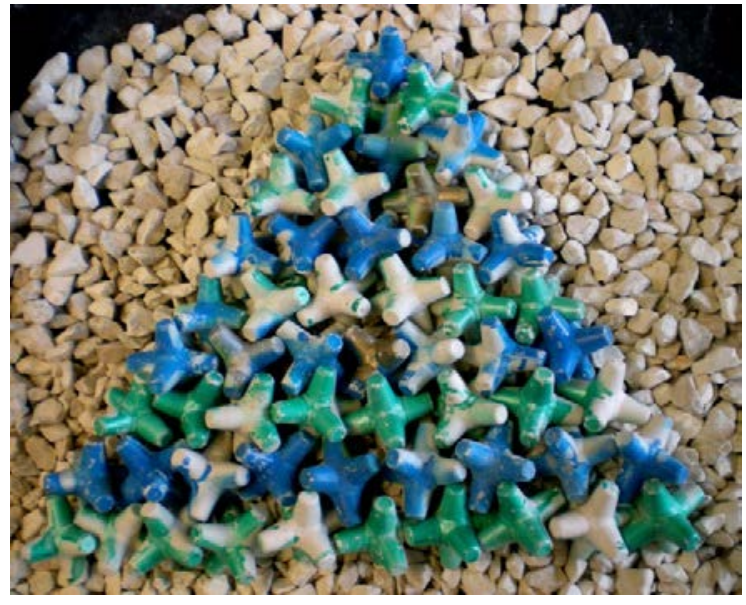

Random placement using conventional underlayer in a diamond-shaped grid

Figure 3: Pictures of test set-up for dry placement tests

\subsection{Testing Programme and Testing Procedure}

Bonfantini (2014) proposed an outline of four placement test series. However, in the present research fourteen different test series were performed to observe the placement of Crablock. The reason for choosing fourteen different test series instead of four tests by Bonfantini (2014), was to get a good idea about the lower and upper limits of packing density of Crablock armour units. To establish a reliable dataset each placing method was repeated three times. Thus, in total 42 tests were performed on the placement of Crablock. The first eleven tests were conducted using large underlayer with the mean weight around $1 / 10^{\text {th }}$ of the armour layer, whereas the last three placement tests were performed with the use of small underlayer material with the mean weight around $1 / 25^{\text {th }}$ of the armour weight, see Table 2 .

It is noted that all the placement tests were carried out without water. Prior to the start of the placing test, underlayer material was placed on top of the slope of the frame. Then Crablock units were placed as single layer armour according to the designed placing grid. It is worth mentioning that all the units were placed only by hand. At first the armour units in the first row were positioned by pointing Crablock units in the designed grid position. Afterwards, the units were set in the higher upslope based on the designed placement pattern and placing grid. Photographs were captured after placement of the armour units in order to describe the placement of the Crablock visually. The grid coordinates of each individual armour unit in case of both horizontal and upslope direction were measured by using a linear scale. 
Table 2: Test programme for dry placement tests

\begin{tabular}{|c|c|c|c|c|c|c|}
\hline $\begin{array}{c}\text { Test } \\
\text { Series No. }\end{array}$ & $\begin{array}{c}\text { Placement } \\
\text { Grid }\end{array}$ & $\begin{array}{c}\text { Designed } \\
\text { Placement Pattem }\end{array}$ & Underlayer & $\begin{array}{c}\text { Designed Hor. } \\
\text { Placement Dis. (D) }\end{array}$ & $\begin{array}{c}\text { Designed Up. } \\
\text { Placement Dis. (D) }\end{array}$ & $\begin{array}{c}\text { Packing Density } \\
\text { Co-efficient, } \boldsymbol{\phi}\end{array}$ \\
\hline 1 & Rectangular & Uniform & 11 to $16 \mathrm{~mm}$ & $0.71 \mathrm{D}$ & $0.57 \mathrm{D}$ & 0.71 \\
\hline 2 & Rectangular & Uniform & 11 to $16 \mathrm{~mm}$ & $0.65 \mathrm{D}$ & $0.60 \mathrm{D}$ & 0.74 \\
\hline 3 & Rectangular & Uniform & 11 to $16 \mathrm{~mm}$ & $0.75 \mathrm{D}$ & $0.65 \mathrm{D}$ & 0.59 \\
\hline 4 & Rectangular & Uniform & 11 to $16 \mathrm{~mm}$ & $0.80 \mathrm{D}$ & $0.60 \mathrm{D}$ & 0.60 \\
\hline 5 & Diamond & Uniform & 11 to $16 \mathrm{~mm}$ & $0.60 \mathrm{D}$ & $0.50 \mathrm{D}$ & 0.96 \\
\hline 6 & Diamond & Uniform & 11 to $16 \mathrm{~mm}$ & $0.70 \mathrm{D}$ & $0.60 \mathrm{D}$ & 0.68 \\
\hline 7 & Diamond & Uniform & 11 to $16 \mathrm{~mm}$ & $0.80 \mathrm{D}$ & $0.65 \mathrm{D}$ & 0.55 \\
\hline 8 & Rectangular & Random & 11 to $16 \mathrm{~mm}$ & $0.71 \mathrm{D}$ & $0.57 \mathrm{D}$ & 0.71 \\
\hline 9 & Rectangular & Random & 11 to $16 \mathrm{~mm}$ & $0.65 \mathrm{D}$ & $0.60 \mathrm{D}$ & 0.74 \\
\hline 10 & Rectangular & Random & 11 to $16 \mathrm{~mm}$ & $0.75 \mathrm{D}$ & $0.65 \mathrm{D}$ & 0.59 \\
\hline 11 & Diamond & Random & 11 to $16 \mathrm{~mm}$ & $0.70 \mathrm{D}$ & $0.60 \mathrm{D}$ & 0.68 \\
\hline 12 & Rectangular & Uniform & 7 to $11 \mathrm{~mm}$ & $0.71 \mathrm{D}$ & $0.57 \mathrm{D}$ & 0.71 \\
\hline 13 & Rectangular & Uniform & 7 to $11 \mathrm{~mm}$ & $0.65 \mathrm{D}$ & $0.60 \mathrm{D}$ & 0.74 \\
\hline 14 & Rectangular & Uniform & 7 to $11 \mathrm{~mm}$ & $0.75 \mathrm{D}$ & $0.65 \mathrm{D}$ & 0.59 \\
\hline
\end{tabular}

In which, $\mathrm{D}$ is the Height of Crablock unit, $\phi$ is the Packing density coefficient = Packing density $\mathrm{X} \mathrm{D}_{\mathrm{n}}{ }^{2}$ and $\mathrm{D}_{\mathrm{n}}$ is the nominal diameter of Crablock.

\section{WAVE FLUME TESTS}

2D flume tests at small scale were carried out at the Fluid Mechanics Laboratory of the Faculty of Civil Engineering and Geosciences at Delft University of Technology, Netherlands, in cooperation with IHE DELFT. All tests were executed with the use of small Crablock units with an average mass of $63.7 \mathrm{~g}$.

\subsection{Model Set-Up}

The model set-up was established by considering the small scale set-up of Accropode (Van der Meer, 1987), the set-up of Xbloc (DMC, 2003) and the set-up of Bruce et al. (2009) for rubble mound breakwaters with various types of armour units. The designed model rubble mound breakwater consisted of single layer Crablock armour, an underlayer, core, a toe structure and a crest wall, see Figure 4. In this experimental research, the slope of the Crablock armour was kept at 1:4/3 similar to Accropode, Core-loc and Xbloc. A crest height of 1.2 times of design wave height $\left(\mathrm{H}_{\mathrm{sD}}\right)$ was chosen to allow for some overtopping under design conditions. This design significant wave height has a stability number around 2.8. This clearly indicates that wave overtopping over the crest of breakwater will be a lot more for significant wave heights beyond the design significant wave height. However, to investigate the influence of the crest height on hydraulic stability and overtopping, a crest height of $1.6 \mathrm{x}$ design wave height $\left(\mathrm{H}_{\mathrm{sD}}\right)$ was also tested, by rebuilding the cross-section. Note that such a crest height may be outside or at the edge of a real breakwater design. 


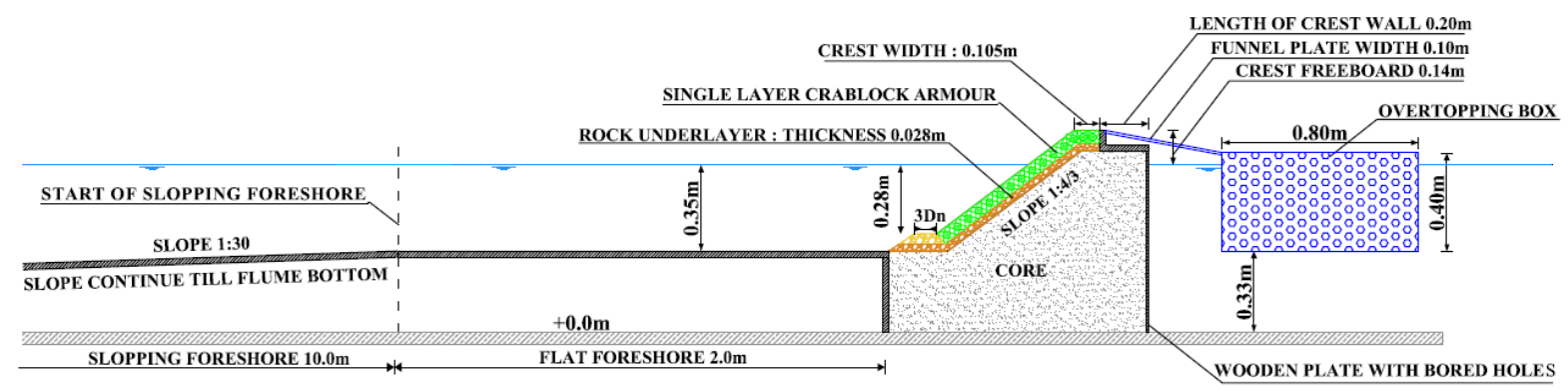

Figure 4: Cross-section of breakwater with crest height $1.2 \mathrm{X} \mathrm{H}_{\mathrm{sD}}$; tests 1-8

To resemble a sea bathymetry a foreshore of 1:30 was constructed on the bottom of the flume. The length of the sloping foreshore was $10 \mathrm{~m}$, which gives a depth at the artificial bottom that is $0.33 \mathrm{~m}$ less than at the deeper part of the flume. Moreover, a horizontal foreshore of $2 \mathrm{~m}$ was considered in front of the structure toe in order to put wave gauges to measure wave heights at this structure toe.

The design stability number governs the design of the geometry of the cross-section and the test programme (Bruce et al., 2009). To design the geometry for the tests on Crablock a stability number of 2.8 was chosen, comparable with Xbloc, Core-loc and Accropode. The design wave height can then be estimated from the known stability number:

Stability number $=\mathrm{H}_{\mathrm{sD}} / \Delta \mathrm{D}_{\mathrm{n}}=2.8$.

$\mathrm{H}_{\mathrm{sD}}=$ Design significant wave height; $\Delta=$ relative mass density $=1.36$ and $\mathrm{D}_{\mathrm{n}}=0.030 \mathrm{~m}$. This gives a design wave height of $\mathrm{H}_{\mathrm{sD}}=0.114 \mathrm{~m}$.

The water depth at the structure was $0.35 \mathrm{~m}$, that means approximately 3 times the design wave height. In order to have water a depth of $0.35 \mathrm{~m}$ at the structure, the water depth at deep water was kept at $0.68 \mathrm{~m}$. For most of the tests (test series 1 to 8), the water depth on top of the toe was $0.28 \mathrm{~m}$, giving a ratio of 0.80 between water depth on top of the toe and in front of the toe.

\subsection{Wave Generation and Measurements}

The 2D wave flume has a length of approximately $45 \mathrm{~m}$, a width of $0.80 \mathrm{~m}$ and a depth of $1.0 \mathrm{~m}$. The theoretical maximum water depth is restricted to $0.90 \mathrm{~m}$ to prevent the waves overtopping over the sidewalls of the flume. The sidewalls of the flume are made of glass. A wave generator is available to generate random waves. Furthermore, an active reflection compensation system has been equipped with the wave generator to compensate for reflected waves from the structure. The wave reflection compensation ensures the generation of the desired waves in the flume without the effect of re-reflection at the wave board.

Wave heights were measured with the use of wave gauges along the flume. Eight wave gauges were used in the wave flume tests. One set with three gauges (numbers 4, 5 and 6) was positioned at the horizontal foreshore of $2 \mathrm{~m}$, close to the structure, in order to determine the incident wave heights at structure. The position of wave gauges was determined regarding to the 
3-wave gauge approach described by Mansard and Funke (1980). This allows dividing the reflected and incoming waves with the use of the least square method. Furthermore, in order to measure the wave heights at deep water another group of three wave gauges (numbers 1, 2 and 3) have been placed far from the structure at a water depth of $0.68 \mathrm{~m}$. One wave gauge was placed at the crest of the breakwater (number 7) to measure the number of overtopping waves. In order to measure the water level in the overtopping box, one water level gauge (number 8) was placed in the overtopping box.

\subsection{Test Programme and Procedure}

Regarding to the literature the important parameters governing the geometrical design of breakwaters were found to be placement pattern, packing density, crest height and wave steepness in terms of wave height and wave length (Bonfantini, 2014). The placing grid, orientation of units and packing density were selected mainly based on the results of the dry placement tests. With considering the important design parameters, laboratory facility and available time for testing, in total ten test series were performed on stability and wave overtopping of the Crablock armour slope. Moreover, two test series were executed for comparison with wave overtopping, using a smooth (wooden) slope of 1 in 4/3. Also, two test series (tests 13 and 14) were performed without the presence of a structure in order to determine the incident wave heights in front of the structure, without reflection from the structure in place.

The following two wave steepnesses have been used: $s_{m-1,0}=0.02$ and 0.04 at deep water, see Table3. The spectral period $\mathrm{T}_{\mathrm{m}-1,0}$ was used to calculate the wave steepness as well as the "deep water wave length": $\mathrm{s}_{\mathrm{m}-1,0}=2 \pi \mathrm{H}_{\mathrm{s}} /\left(\mathrm{gT}_{\mathrm{m}-1,0}{ }^{2}\right)$ One of the major differences of this experimental research with the set up by Bruce et al. (2009) is that in this research a sloping foreshore was used in front of the structure instead of a horizontal foreshore. Due to the sloping foreshore and limited water depth, a spectral wave steepness $s_{m-1,0}$ higher than 0.04 could not be obtained in this experimental research, which was caused by wave breaking. Therefore, the higher wave steepness for this small-scale test has been fixed to $s_{m-1,0}=0.04$. All tests were performed with increasing wave heights to examine the behaviour of the armour layer and wave overtopping. The maximum significant wave height assumed for this experimental investigation was $0.20 \mathrm{~m}$ at the toe of the structure and $0.25 \mathrm{~m}$ at deep water; the design wave height with a stability number of 2.8 corresponds to $0.114 \mathrm{~m}$. The significant wave height $\left(\mathrm{H}_{\mathrm{m} 0}\right)$ for a test series started with a low significant wave height of $0.07 \mathrm{~m}$, which continued to increase in each consecutive test till the maximum wave height of $0.25 \mathrm{~m}$ at deep water. The wave periods together with the wave heights and the wave steepness are presented in Table 4.

Table 3: Test programme for the small scale physical model tests in the wave flume 


\begin{tabular}{|c|c|c|c|c|c|c|c|c|c|}
\hline $\begin{array}{c}\text { Test } \\
\text { Series No. }\end{array}$ & $\begin{array}{c}\text { Placement } \\
\text { Grid }\end{array}$ & $\begin{array}{c}\text { Designed } \\
\text { Placement Pattemn }\end{array}$ & Underlayer & \begin{tabular}{|c|} 
Designed Hor. \\
Placement Dis. (D)
\end{tabular} & \begin{tabular}{|c|} 
Designed Up. \\
Placement Dis. (D)
\end{tabular} & $\begin{array}{c}\text { Packing Density } \\
\text { Co-efficient, } \phi\end{array}$ & $\begin{array}{c}\text { Crest } \\
\text { freeboard (m) }\end{array}$ & $\begin{array}{l}\text { Deep water wave } \\
\text { steepness, } s_{m-1,0}\end{array}$ & $\begin{array}{c}\text { Water depth near } \\
\text { structure (m) } \\
\end{array}$ \\
\hline 1 & Rectangular & Uniform & 7 to $11 \mathrm{~mm}$ & $0.65 \mathrm{D}$ & $0.64 \mathrm{D}$ & 0.69 & 0.140 & 0.04 & 0.35 \\
\hline 2 & Rectangular & Uniform & 7 to $11 \mathrm{~mm}$ & $0.65 \mathrm{D}$ & $0.64 \mathrm{D}$ & 0.69 & 0.140 & 0.02 & 0.35 \\
\hline 3 & Diamond & Uniform & 11 to $16 \mathrm{~mm}$ & $0.75 \mathrm{D}$ & $0.61 \mathrm{D}$ & 0.63 & 0.140 & 0.04 & 0.35 \\
\hline 4 & Diamond & Uniform & 11 to $16 \mathrm{~mm}$ & $0.75 \mathrm{D}$ & $0.61 \mathrm{D}$ & 0.63 & 0.140 & 0.02 & 0.35 \\
\hline 5 & Rectangular & Uniform & 7 to $11 \mathrm{~mm}$ & $0.68 \mathrm{D}$ & $0.64 \mathrm{D}$ & 0.66 & 0.140 & 0.04 & 0.35 \\
\hline 6 & Rectangular & Uniform & 7 to $11 \mathrm{~mm}$ & $0.68 \mathrm{D}$ & $0.64 \mathrm{D}$ & 0.66 & 0.140 & 0.02 & 0.35 \\
\hline 7 & Rectangular & Uniform & 7 to $11 \mathrm{~mm}$ & $0.71 \mathrm{D}$ & $0.64 \mathrm{D}$ & 0.63 & 0.140 & 0.04 & 0.35 \\
\hline 8 & Rectangular & Uniform & 7 to $11 \mathrm{~mm}$ & $0.71 \mathrm{D}$ & $0.64 \mathrm{D}$ & 0.63 & 0.140 & 0.02 & 0.35 \\
\hline 9 & Rectangular & Uniform & 7 to $11 \mathrm{~mm}$ & $0.68 \mathrm{D}$ & $0.64 \mathrm{D}$ & 0.66 & 0.185 & 0.04 & 0.35 \\
\hline 10 & Rectangular & Uniform & 7 to $11 \mathrm{~mm}$ & $0.68 \mathrm{D}$ & $0.64 \mathrm{D}$ & 0.66 & 0.185 & 0.02 & 0.35 \\
\hline 11 & \multicolumn{6}{|c|}{ Smooth $1: 4 / 3$ slope } & 0.185 & 0.04 & 0.35 \\
\hline 12 & \multicolumn{6}{|c|}{ Smooth $1: 4 / 3$ slope } & 0.185 & 0.02 & 0.35 \\
\hline 13 & \multicolumn{6}{|c|}{ Tests without struture } & $\ldots \ldots \ldots$ & 0.04 & $\ldots \ldots \ldots$ \\
\hline 14 & \multicolumn{6}{|c|}{ Tests without struture } & ......... & 0.02 & ......... \\
\hline
\end{tabular}

Table 4: Input wave conditions

\begin{tabular}{|c|c|c|c|c|c|c|c|}
\hline \multicolumn{9}{|c|}{$\mathrm{T}_{\mathrm{m}-1,0}[\mathrm{~s}]$} \\
\hline $\mathrm{s}_{\mathrm{m}-1,0}[-] \backslash \mathrm{H}_{\mathrm{m} 0}[\mathrm{~m}]$ & 0.07 & 0.10 & 0.13 & 0.16 & 0.19 & 0.22 & 0.25 \\
\hline 0.02 & 1.57 & 1.88 & 2.14 & 2.38 & 2.59 & 2.79 & 2.97 \\
\hline 0.04 & 1.13 & 1.3 & 1.45 & 1.59 & 1.72 & 1.84 & 1.95 \\
\hline
\end{tabular}

Each test consisted of a sequence of approximately 1000 irregular waves of a JONSWAP spectrum with peak enhancement factor, $\gamma=3.3$. At the start of each test, the wave flume was filled up to the required water level. Then before taking any reading, wave gauges have been fixed according to the designed position and calibrated to avoid error in measurements of wave heights. Moreover, cameras and a video recorder were set up at a fixed position to capture the photographs and video. To capture the position of armour units in their initial condition photographs were taken before the start of each test.

Then waves have been generated based on the test wave conditions. The test started with a low wave height in order to cause the first small settlements and to protect the armour layer from sudden failure. In each test wave heights and periods were increased until failure of the armour slope. Once the armour slope or underlayer was damaged due to waves, the armour layer were reconstructed for the next test series. At the end of every step, the water level in the overtopping box was determined to measure the volume of overtopping waves. It should be noted that the number of waves overtopping the structure was calculated from the record of the wave gauge placed at the crest of the breakwater. Photographs were captured at the end of each test. The test set-up and procedure for the 2D wave flume tests on Crablock has been reported more in depth by Salauddin, 2015.

\section{Pull Tests}

\subsection{Model Set-Up}


To determine the interlocking properties pull tests have been introduced. The level of interlocking is defined as the interlocking degree. This is the ratio between the extraction force and the individual weight of the unit. The extraction force was measured just after placement of the armour in dry conditions and after exposure of waves in the flume. The pull tests after the flume test on hydraulic stability have been performed to determine the influence of settlement on the interlocking degree. The maximum force needed for the extraction has been used for the interlocking degree. To secure the extraction perpendicular from the slope a frame was used. For the tests in dry conditions the cross section presented in Figure 5 was applied.
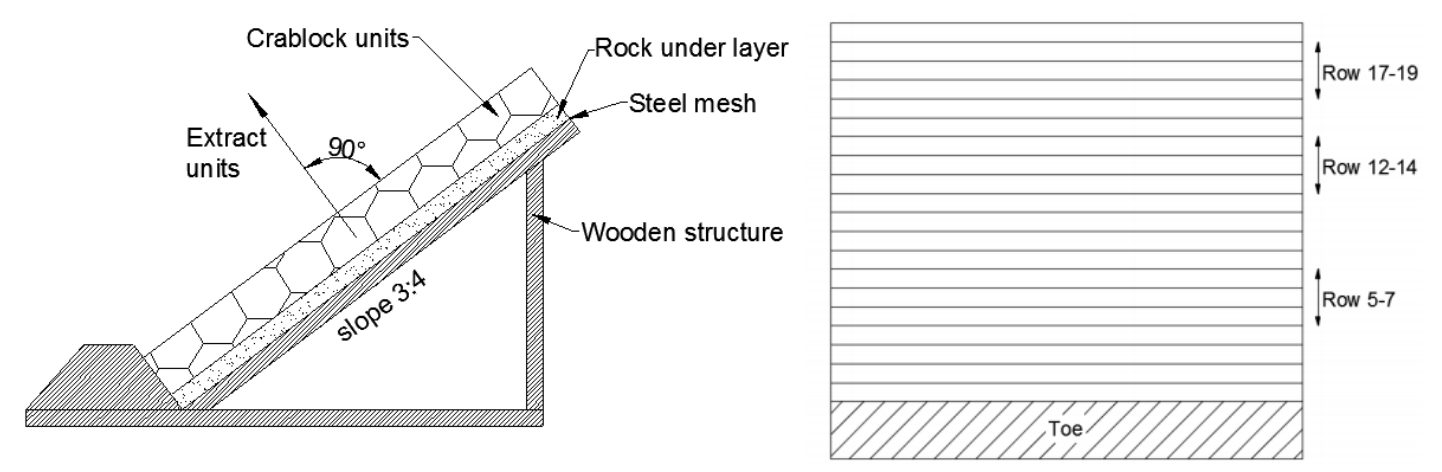

Figure 5: Test set up of pull tests

\subsection{Testing Procedure}

The pull tests provide extra information to clarify the behaviour of the Crablock units. To make a comparison between an armour with and without settlement it is important to use the same configurations in the dry tests as used by the flume tests. Not all flume tests on hydraulic stability have been used for the pull tests. The Crablock units were extracted from several heights on the slope. This was performed to investigate the influence of the additional weight of the units above on the interlocking. At each height on the slope multiple units were extracted to improve the accuracy. See Broere, 2015 for the full description of the procedure.

\section{RESULTS AND DISCUSSIONS}

\section{1 Placement Tests}

\subsubsection{Visual Observation and Experience of Placing}

The placement pattern and the general accuracy of the placement of the armour layer has first been analysed by visual inspection of the armour units. A summary of the results is given in Table 5.

Table 5: Overview of the results of visual inspection in all test series 


\begin{tabular}{|c|c|c|c|c|c|c|c|}
\hline $\begin{array}{c}\text { Test } \\
\text { Series No. }\end{array}$ & $\begin{array}{c}\text { Placement } \\
\text { Grid }\end{array}$ & Underlayer & $\begin{array}{c}\text { Designed Hor. } \\
\text { Placement Dis. (D) }\end{array}$ & $\begin{array}{c}\text { Designed Up. } \\
\text { Placement Dis. (D) }\end{array}$ & $\begin{array}{c}\text { Designed } \\
\text { Placement Pattem }\end{array}$ & $\begin{array}{c}\text { Obtained } \\
\text { Placement Pattern }\end{array}$ & Observation \\
\hline 1 & Rectangular & 11 to $16 \mathrm{~mm}$ & $0.71 \mathrm{D}$ & $0.57 \mathrm{D}$ & Uniform & Not $100 \%$ Uniform & interlocked \\
\hline 2 & Rectangular & 11 to $16 \mathrm{~mm}$ & $0.65 \mathrm{D}$ & $0.60 \mathrm{D}$ & Uniform & Not $100 \%$ Uniform & good interlocked \\
\hline 3 & Rectangular & 11 to $16 \mathrm{~mm}$ & $0.75 \mathrm{D}$ & $0.65 \mathrm{D}$ & Uniform & Not $100 \%$ Uniform & loose units \\
\hline 4 & Rectangular & 11 to $16 \mathrm{~mm}$ & $0.80 \mathrm{D}$ & $0.60 \mathrm{D}$ & Uniform & Not $100 \%$ Uniform & lot of loose units \\
\hline 5 & Diamond & 11 to $16 \mathrm{~mm}$ & $0.60 \mathrm{D}$ & $0.50 \mathrm{D}$ & Uniform & Random & lot of loose units \\
\hline 6 & Diamond & 11 to $16 \mathrm{~mm}$ & $0.70 \mathrm{D}$ & $0.60 \mathrm{D}$ & Uniform & Random & interlocked \\
\hline 7 & Diamond & 11 to $16 \mathrm{~mm}$ & $0.80 \mathrm{D}$ & $0.65 \mathrm{D}$ & Uniform & Random & lot of loose units \\
\hline 8 & Rectangular & 11 to $16 \mathrm{~mm}$ & $0.71 \mathrm{D}$ & $0.57 \mathrm{D}$ & Random & Random & interlocked \\
\hline 9 & Rectangular & 11 to $16 \mathrm{~mm}$ & $0.65 \mathrm{D}$ & $0.60 \mathrm{D}$ & Random & Random & interlocked but too narrow \\
\hline 10 & Rectangular & 11 to $16 \mathrm{~mm}$ & $0.75 \mathrm{D}$ & $0.65 \mathrm{D}$ & Random & Random & loose units \\
\hline 11 & Diamond & 11 to $16 \mathrm{~mm}$ & $0.70 \mathrm{D}$ & $0.60 \mathrm{D}$ & Random & Random & good interlocked \\
\hline 12 & Rectangular & 7 to $11 \mathrm{~mm}$ & $0.71 \mathrm{D}$ & $0.57 \mathrm{D}$ & Uniform & Uniform & interlocked \\
\hline 13 & Rectangular & 7 to $11 \mathrm{~mm}$ & $0.65 \mathrm{D}$ & $0.60 \mathrm{D}$ & Uniform & Uniform & good interlocked \\
\hline 14 & Rectangular & 7 to $11 \mathrm{~mm}$ & $0.75 \mathrm{D}$ & $0.65 \mathrm{D}$ & Uniform & Uniform & loose units \\
\hline
\end{tabular}

To scrutinize the placement pattern of Crablock in a rectangular grid, tests 1,8 and 12 were compared. All the three tests were performed with the same designed horizontal and upslope placement distance. However, it was observed that the small underlayer (test 12) certainly provided a better uniform placement in comparison to a conventional underlayer (test 1) in a similar designed rectangular grid. It was noticed that a uniform pattern (tests 1 and 12) looked more interlocked compared to a random pattern (test 8). Furthermore, from Table 4 it can be concluded that a pre-defined uniform placement pattern could not be achieved for all cases. Also, a lot of loose units were observed for some tests, what is not allowable in a real situation.

\subsubsection{Measurements on Accuracy of Placement}

The accuracy of the placement can be analysed by determining the average deviations of units from the designed grid position. The accuracy of the placement varied with different grids and with different orientation of units. Based on the measured position of the units, the deviation of each individual unit was determined. The average deviation of units has been determined for all the placement test series. For placement test series 13 (observation: good interlocking), the deviation of each individual unit from the designed placement grid is shown in Figure 6 as an example. Figure 6 shows that the average horizontal deviation of the units amounted to 0.01D and the average upslope deviation of the units to $-0.07 \mathrm{D}$, where deviations to the right and upwards have been defined as positive. In this test relatively small deviations of units have been observed, which indicates that this designed grid is also applicable in prototype situation. 


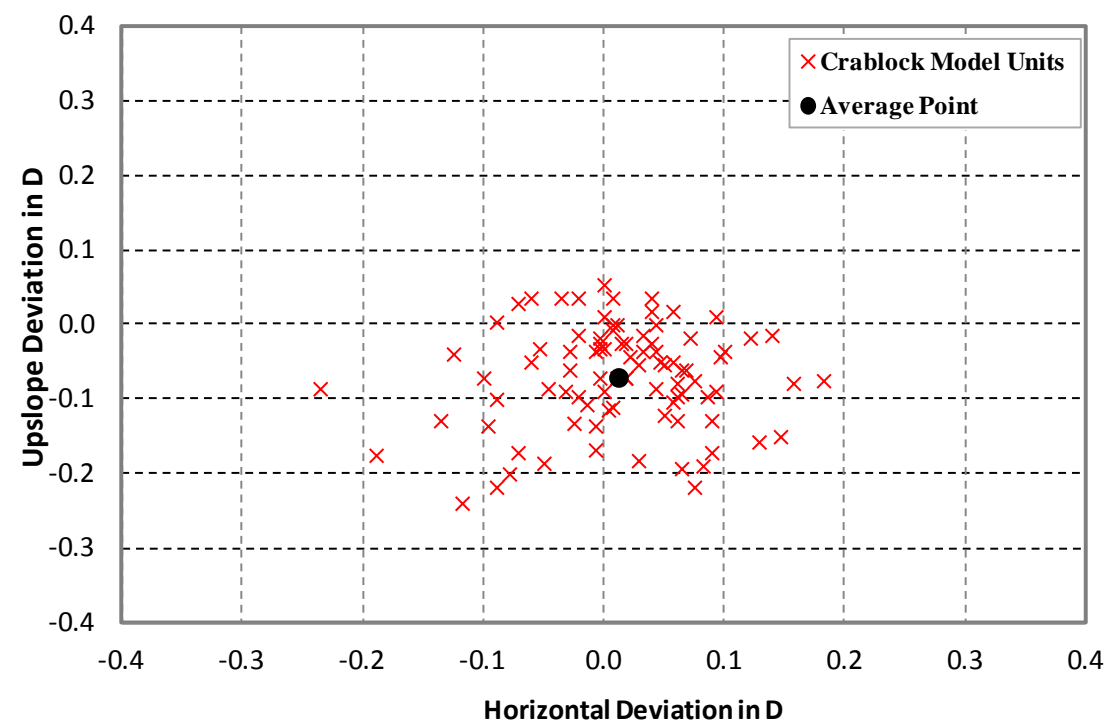

Figure 6: Deviation of units from their intended position (Test 13)

\subsubsection{Packing density}

The average packing density for each test was determined by calculating the mean of the local packing densities of each unit regarding the calculated horizontal and upslope placement distance for each specific unit. The measured horizontal and upslope placement distances diverged from the theoretically predicted value. 


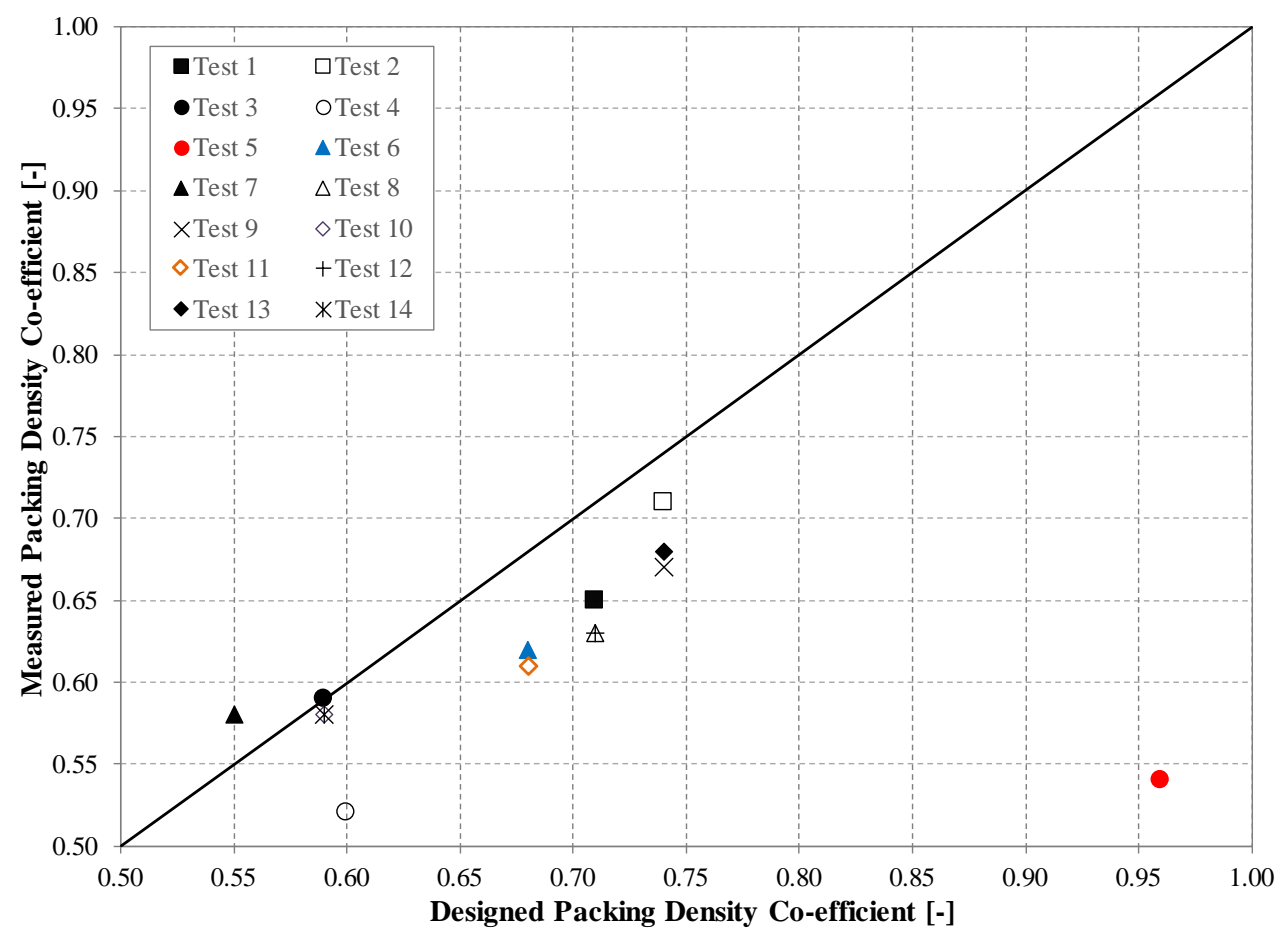

Figure 7: Designed nominal packing density co-efficient against measured nominal packing density co-efficient

Figure 7 shows a comparison between the nominal packing density as designed and the measured one in each individual test series. The test results show that in both the diamond-shaped and rectangular grid, the measured packing density was lower for the randomly oriented armour in comparison to uniformly oriented Crablock armour. Moreover, from the test results it can be concluded that a lower packing density of Crablock was obtained with the use of a diamondshaped grid. It can also be concluded that the upslope placement distance is often around 0.63 D.

The rogue point of 0.96 (designed packing density coefficient), indicates that for Test 5, model Crablock units were not possible to place uniformly according to the specific designed grid. The theoretically designed grid with recommended placement distances was very small to place the units in position. From the visual inspection, it was noticed that some of the units were not entirely interacted with other units. Moreover, most of the units displaced from their planned grid position with loosing the diamond pattern, see details in Salauddin, 2015.

From the above results and discussions, it can be concluded that it is possible to obtain a good interlocked uniform pattern of Crablock armour units with a packing density co-efficient of 0.68 on the condition that a relatively small underlayer has to be used. In a diamond-shaped grid, the randomly oriented Crablock units ensure a good interlocked armour with a packing density coefficient of 0.61 . The theoretically designed diamond shaped grid with uniform placement pattern was hardly possible using a conventional rock underlayer and without fixation of the first row.

\section{2 Wave Flume Tests}




\subsubsection{Stability}

\section{Damage based on displacements}

The stability limits for the Crablock may be linked to the stability number, and are given by low or zero values of the relative number of Crablock displaced (extracted) units $\mathrm{N}_{\text {od. }}$. In all cases the structure was stable to a very high wave height, exceeding the set design wave height by far. Note that start of damage in Figure 8 never started for a stability number smaller than 2.8. The wave height in the stability number is given as the average of the highest one-third of the waves $\left(\mathrm{H}_{\mathrm{s}}=\mathrm{H}_{1 / 3}\right)$ and not as the spectral wave height $\mathrm{H}_{\mathrm{m} 0}$.

For the tests with the highest wave steepness $s_{m-1,0}=0.04$ only slight damage was obtained during the physical model tests performed with a packing density co-efficient of $\phi=0.63$ and a rectangular grid, see Figure 8 . The long waves with a lower wave steepness caused damage (extracted units) to the armour layer for all tests, but of course only for very large wave heights. The higher crest level experienced the most severe wave attack on the armour slope, while for the normal crest level the highest waves attacked the armour at the transition from slope to horizontal crest. Settlements caused openings between the units on the upper slope and at the horizontal crest, which resulted in the weakest point of the armour layer. The heavy wave attack at the lowest crest level is therefore focussed on the most vulnerable part. This might explain the lower number of displacements found for the higher crest level with $\phi=0.66$. 

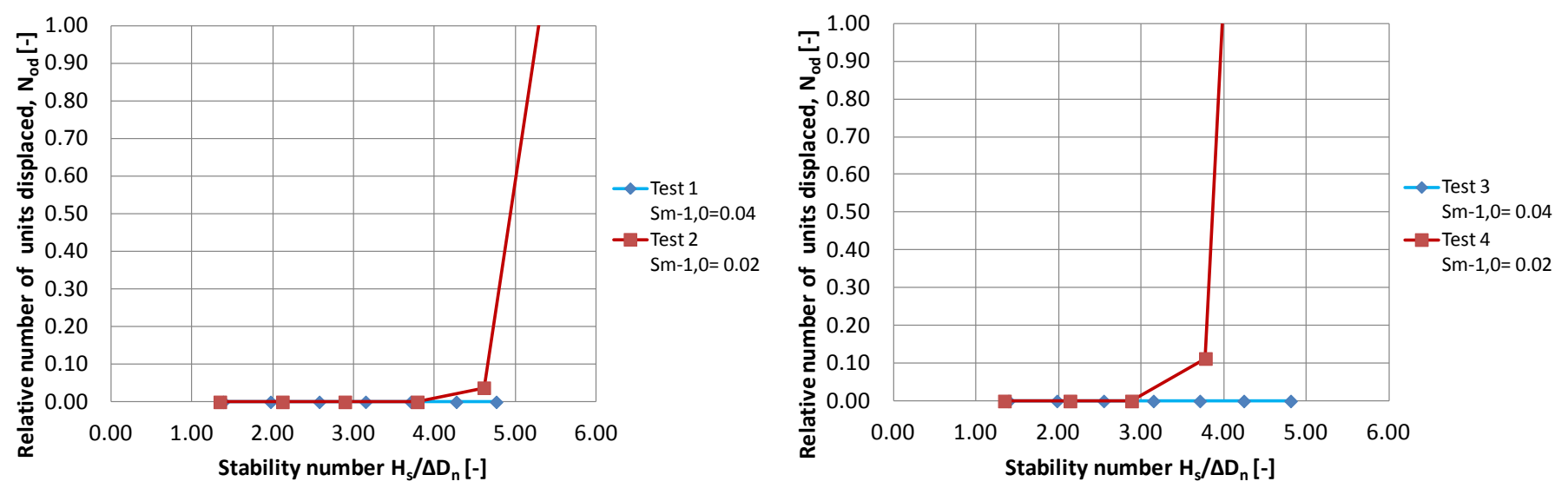

a.

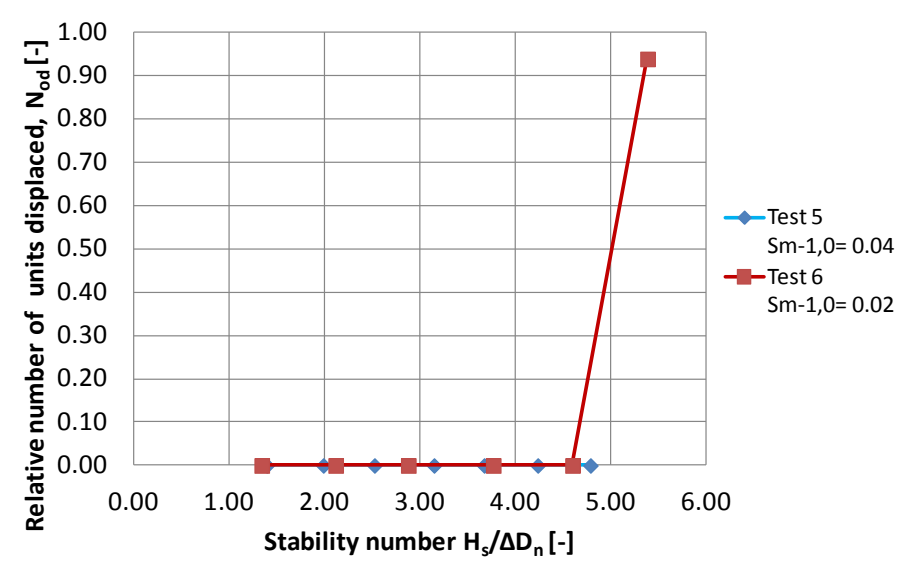

C.

b.

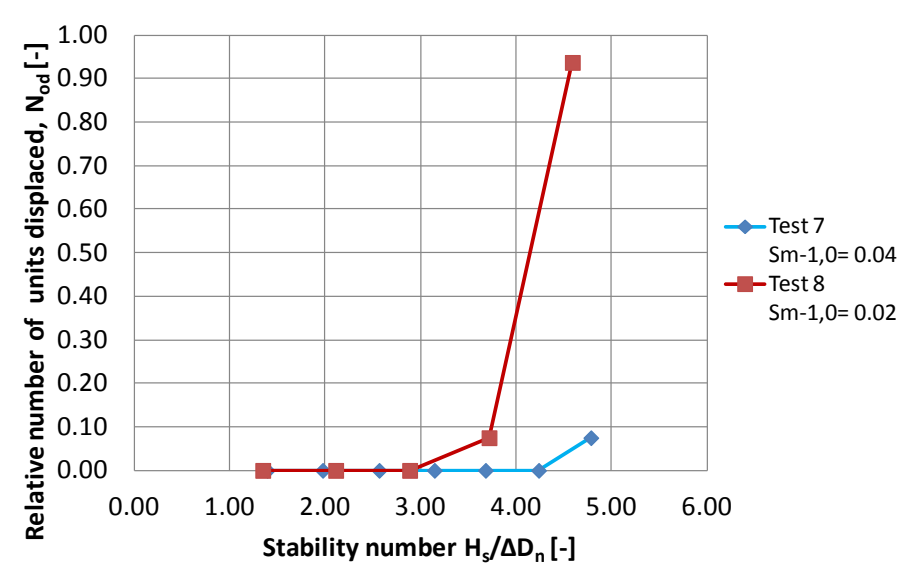

d.

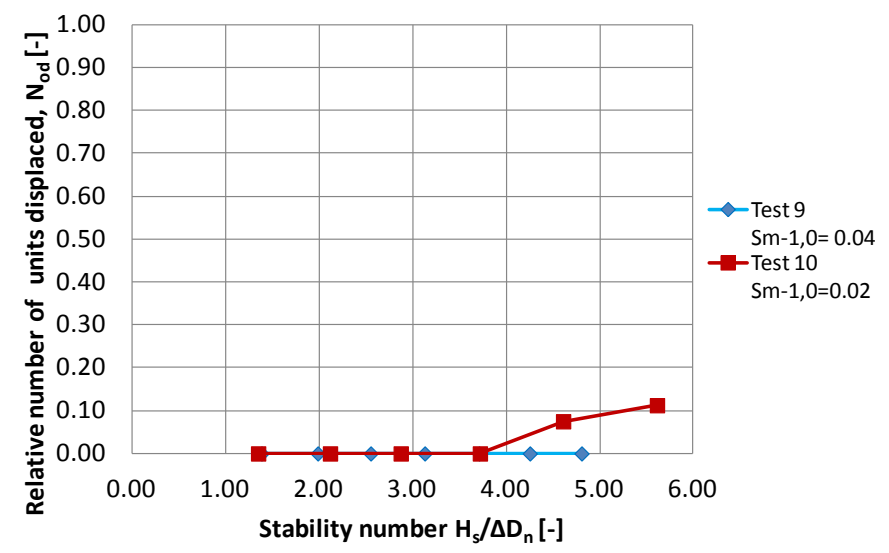

1 unit displacement $=\left[\mathrm{N}_{\mathrm{od}}=0.0375\right]$ Rec. = Rectangular Placement grid Dia. = Diamond Placement grid

e.

Figure 8: $\mathrm{N}_{\text {od }}$ versus stability number $\left(\mathrm{H}_{\mathrm{s}} / \Delta \mathrm{D}_{\mathrm{n}}\right)$ for all tests- a) Rec. grid with $\phi=0.69$, b) Dia. grid with $\phi=0.63$, c) Rec. grid with $\phi=0.66$; d) Rec. grid with $\phi=0.63$ and e) $\phi=0.66$ with higher crest freeboard $\left(\mathrm{R}_{\mathrm{c}}=0.185\right)$

Damage by displacement 
Individual displacements of units were determined by comparing photographs before and after testing and measuring the distance moved or displaced. When concerning a threshold level of displacement within the armour layer $>0.75 \mathrm{D}_{\mathrm{n}}$, the tests series conducted with packing density coefficient of 0.63 showed very large movements in an early stage (settlement within the layer, mainly at the upper part). The settlements larger than $0.75 \mathrm{D}_{\mathrm{n}}$ started around a stability number of 2 for the diamond grid and around stability number of 3 for rectangular grid.

The influence of the crest level on settlement is considerable for the packing density coefficient of 0.66 and the tests with a high crest level resulted in larger settlements. For both steepnesses the displacements for the normal crest level started around a stability number of 4. Although only this packing density was tested for different crest levels, it might be expected that there is some influence on other packing densities as well. The armour layer executed with a $\phi=0.69$ did not show any displacement above the chosen threshold levels at all. Note that in all tests there were 22 rows of Crablock units, which in reality for other single layer units like Accropode and Xbloc is considered as an absolute maximum. For more detailed information see Broere, 2015.

\section{Damage by rocking}

Rocking was obtained by visual inspection during testing. For the rocking behaviour of Crablock a criterion of $\mathrm{N}_{\mathrm{or}}=0.2$ was used to eliminate inaccurate placing of the individual armour units. This criterion represents rocking of about five units. The armour layer executed with a packing density coefficient of $\phi=0.69$ complied this criterion for a stability number of approximately 4 . Looking at $\phi=0.66 / \mathrm{D}_{\mathrm{n}}^{2}$ the rocking criterion was exceeded around a stability number of about 3 for both crest levels. In the tests performed with a packing density coefficient of 0.63 rocking was observed from a stability number of 2 . So, packing density has a significant influence on rocking of units. The progression of rocking movements against stability number is described in detail by Broere, 2015.

\section{Excluding packing density coefficient of 0.63}

When only considering damage by displacements/extractions, the results obtained from a packing density coefficient of 0.63 were acceptable according to Figure 8. Considering the settlement and rocking of the armour layer, a packing density coefficient of 0.63 performed very bad. Large settlements and considerable rocking started already during low stability numbers. Next to this, the settlements resulted in some very loose packed units which rolled over the underlayer. Although the units are robust, rolling of units cannot be accepted in reality in order to prevent possible damage to the unit. A packing density coefficient of 0.63 is therefore considered as too loose and was not considered in the further analysis. Since the maximum $\phi$ achievable for the diamond placement grid is 0.63 , this placement is considered as not applicable for Crablock armour units.

\section{$\underline{\text { Design stability number }}$}

Regarding the results of the analysis on hydraulic stability, start of damage by displacements occurred from a stability number of 4.6, see Figure 8 for packing density co-efficient of $\phi=0.66$ 
and $\phi=0.69$. The wave steepness of 0.04 did not show any damage at all up to the largest possible wave height with a stability number of 4.8. The lower wave steepness of 0.02 gave two times start of damage at a stability number of 4.6 and once (leading also to large damage) at 5.4. The average value for start of damage becomes then 5.0. The wave height is then more than $75 \%$ larger than the assumed design wave height.

The settlement of the units with a threshold level set on $>0.75 \mathrm{D}_{\mathrm{n}}$ started for the higher crest level to become considerable from a stability number of 4.0. For the lower crest level, the units did not exceed this threshold level during the whole test series. Applying a criterion of $\mathrm{N}_{\mathrm{or}}=0.2$ for rocking, the armour layer executed with a packing density co-efficient of 0.69 complied with this criterion for a stability number of approximately 4.0. However, looking at a packing density coefficient of 0.66 the rocking criterion was exceeded around a stability number of about 3.0 for both crest levels.

Single layer units show a brittle failure: up to a large wave height there is no damage, but if for this very large wave height damage occurs, it is also close to complete failure. For this reason, a significant safety factor is required to come to a design value. If no damage occurred during the first 1000 waves, it was assumed that more waves were not able to cause significant more damage. The no-damage criterion is therefore independent of the number of waves.

For Accropode (Van der Meer, 1987), the design stability number was based on a safety factor of 1.5 on the stability number. The average start of damage occurred there for a stability number of 3.7, leading to a design stability number of 2.5 for Accropode, which was accepted by CLI/Sogreah at that time as a design value. Accropode II and Core-locs are a little more stable, which resulted in a design stability number of 2.8. This was also used to design the geometry of the cross-section for the model tests on Crablock. For Xbloc a safety factor of 1.25 has been chosen, also leading to a design stability number of 2.8.

The stability results on Crablock are better than on Accropode or Xbloc. A safety factor on the average start of damage would give a design stability number of 3.3, significantly higher than for the other known single layer units. However, a stability number of about 3 is also the point where the criteria on rocking $\left(\mathrm{N}_{\text {or }}=0.2\right)$ was exceeded. The margin between the design stability number and start of rocking is not known for Accropode but for Xbloc a value of 1.1 is applied (DMC, 2003). This margin of 1.1 may also be applied on Crablock with respect to exceedance of the rocking criteria. A very conservative design value of the stability number is 2.8 and is thereby equal as assumed when preparing the model set-up and is equal to the other single layer units. A less conservative design stability number, but still with a safety factor of 1.5, is a value up to 3.3.

When taking a higher stability number one should realise that the criteria on rocking has to be less strict. This leads to a first approximation for stability as in equation 7. More research is required to come to a final design value.

Design stability number $=\mathrm{H}_{\mathrm{sD}} / \Delta \mathrm{D}_{\mathrm{n}}=$ minimum 2.8, maximum 3.3

\subsubsection{Overtopping}


The mean wave overtopping rate and overtopping percentages over a Crablock armour slope were measured for each test series. In all cases the incident wave height at the toe of the structure was considered, where the wave height was based on the spectrum $\left(\mathrm{H}_{\mathrm{m} 0}\right)$, as this is the wave height that is used in overtopping estimations (EurOtop, 2007).

\section{$\underline{\text { Relative Wave Overtopping Discharges }}$}

The resulting relative wave overtopping discharge $\mathrm{q} / \mathrm{ggH}_{\mathrm{m} 0}{ }^{3}$ as a function of the relative crest freeboard $\left(\mathrm{R}_{\mathrm{c}} / \mathrm{H}_{\mathrm{m} 0}\right)$ is presented in Figure 9. The graph shows that test series with irregular placement of Crablock result in almost the same overtopping as the other test series with regular placement of Crablock units, for the same wave steepness. To give an example, the comparison of measured wave overtopping in test series 1, 3, 5 and 7 (same wave period) demonstrates that regular placement (test 3) hardly has any influence on overtopping; see Figure 9. Furthermore, for the tests with the same wave steepness overtopping results did not vary much between the different test series, with the change in packing density, see again Figure 9. For instance, test series 1, 5 and 7 were performed with a uniform placement pattern with the same configuration, but with a different packing density of armour layer. Based on the test results it can be concluded that the variation in packing density did not really change the overtopping behaviour of these test series.

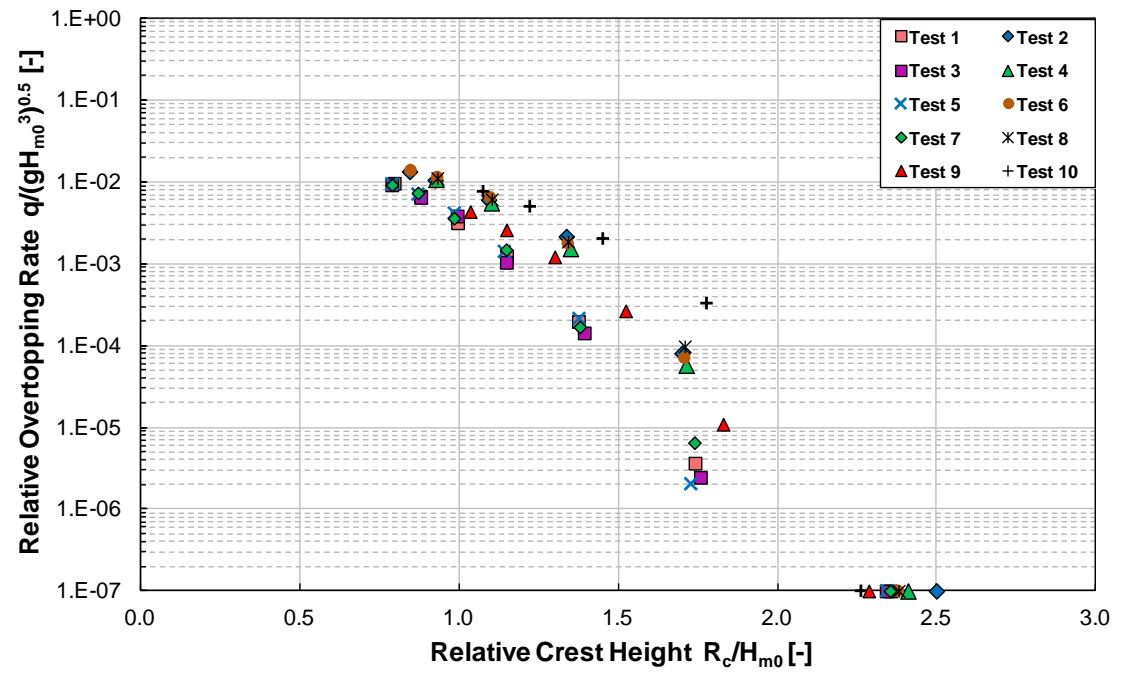

Figure 9: Relative overtopping discharge as a function of relative freeboard 


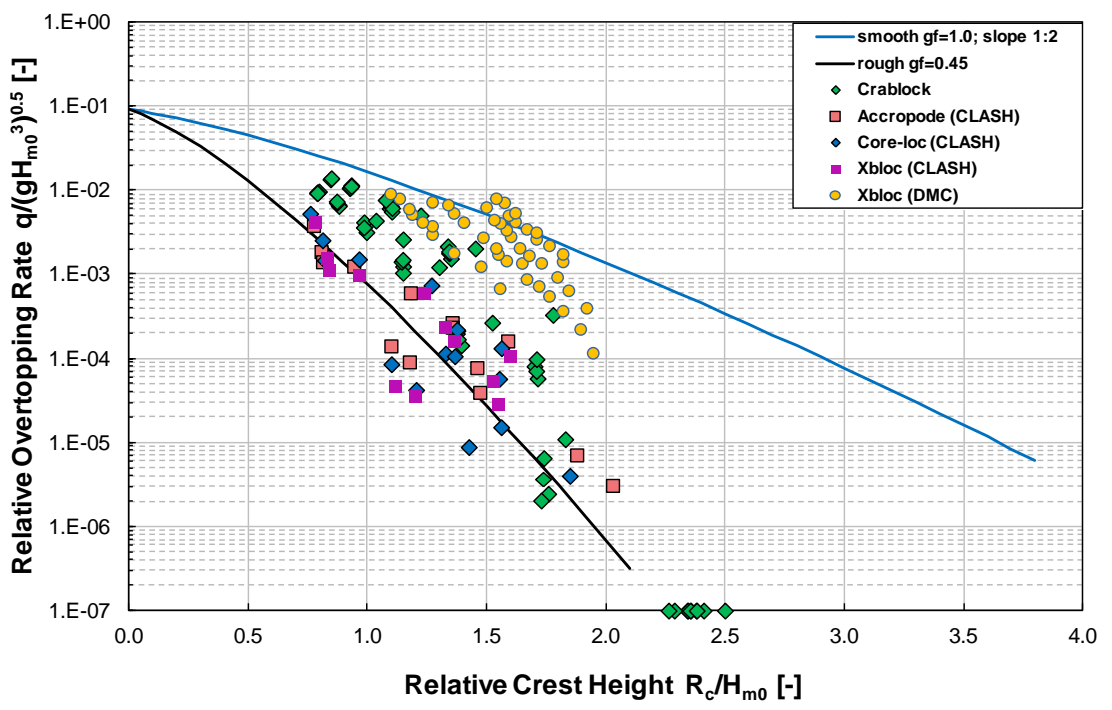

Figure 10: Test results compared to empirical prediction and other monolayer units

Figure 10 presents the comparison between the measured dimensionless overtopping discharges over Crablock from the flume tests versus the predictions by the new empirical formula from Van der Meer and Bruce (2014). Besides an empirical prediction with an assumed roughness factor of $\gamma_{\mathrm{f}}=0.45$, the reference line for a smooth slope has been drawn with $\gamma_{\mathrm{f}}=1.0$. Figure 10 also compares the test results with other single layer units extracted from the CLASH (2004) results described by Bruce et al. (2009) and from 2D model tests on Xbloc by DMC (2003). Based on Figure 10 it is also observed that in almost all the cases the empirical formula $\left(\gamma_{\mathrm{f}}=\right.$ 0.45) underestimates the wave overtopping discharge over Crablock slopes, compared to the test measurements. Also, for high waves the overtopping over Crablock is somewhat larger in comparison to the overtopping over other single layer units, like Accropode, Core-loc and Xbloc (CLASH, 2004). However, a completely different scenario is observed in case of Xbloc measurements by DMC (2003). From Figure 10, it is recognised that overtopping over Xbloc by DMC (2003) is significantly higher compared to the empirical line of rough armour, Bruce et al. (2009) and Crablock.

\section{Percentage of Wave Overtopping}

Figure 11 shows the measured percentage of overtopping waves with respect to a dimensionless crest height. In this research the nominal diameter $\left(D_{n}\right)$ of the Crablock was constant thus the percentage of overtopping waves varied with the significant wave height $\left(\mathrm{H}_{\mathrm{m} 0}\right)$ at the toe and the armour freeboard $\left(A_{c}\right)$. The resulting graph clearly shows that the percentage of overtopping waves increases with the increase of significant wave height at the toe of breakwater, while it decreases with the increase of crest freeboard. The test results showed that in general the percentage of waves overtopping the structure were a bit higher for longer wave periods than for high wave steepness. For example, from Figure 11 it is seen that tests with a wave steepness of $\mathrm{S}_{\mathrm{m}-1,0}=0.02$ gave higher percentages of overtopping waves compared to the tests with a wave steepness of $s_{m-1,0}=0.04$. 


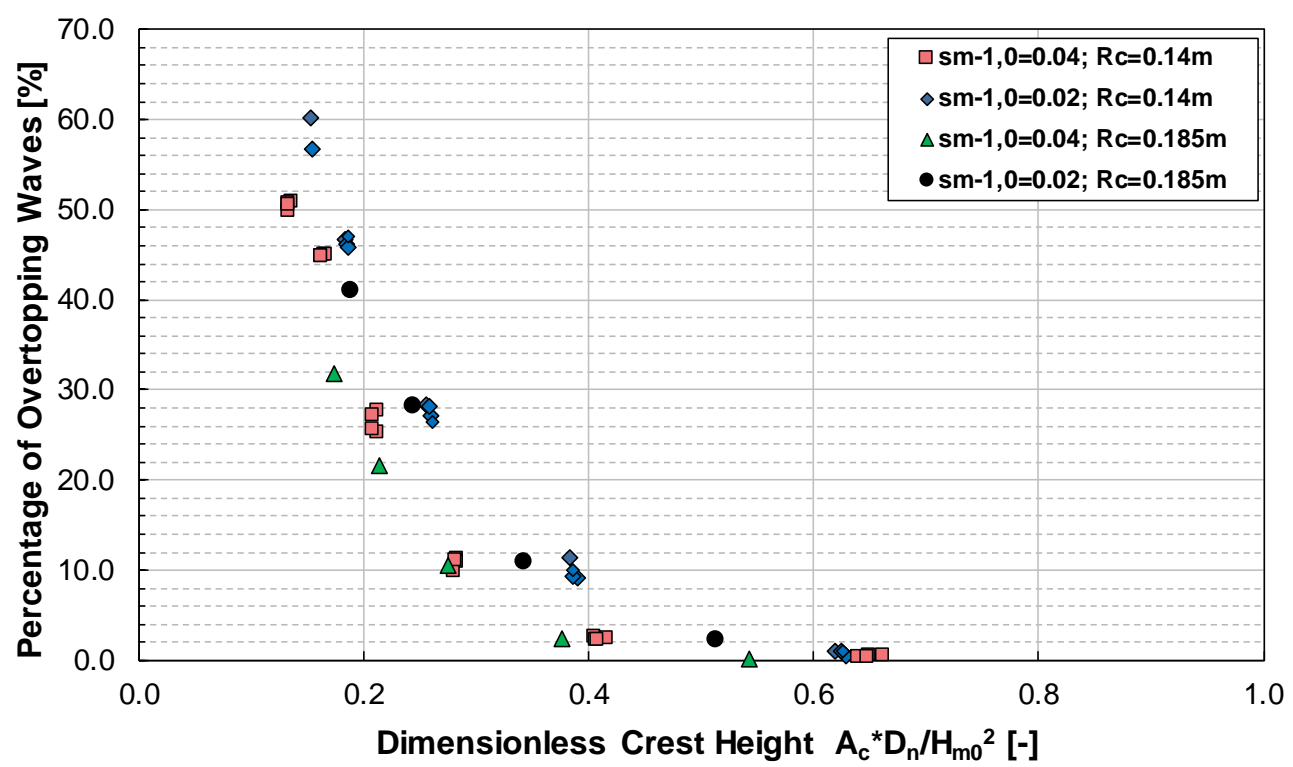

Figure 11: Percentage of wave overtopping as a function of dimensionless crest freeboard

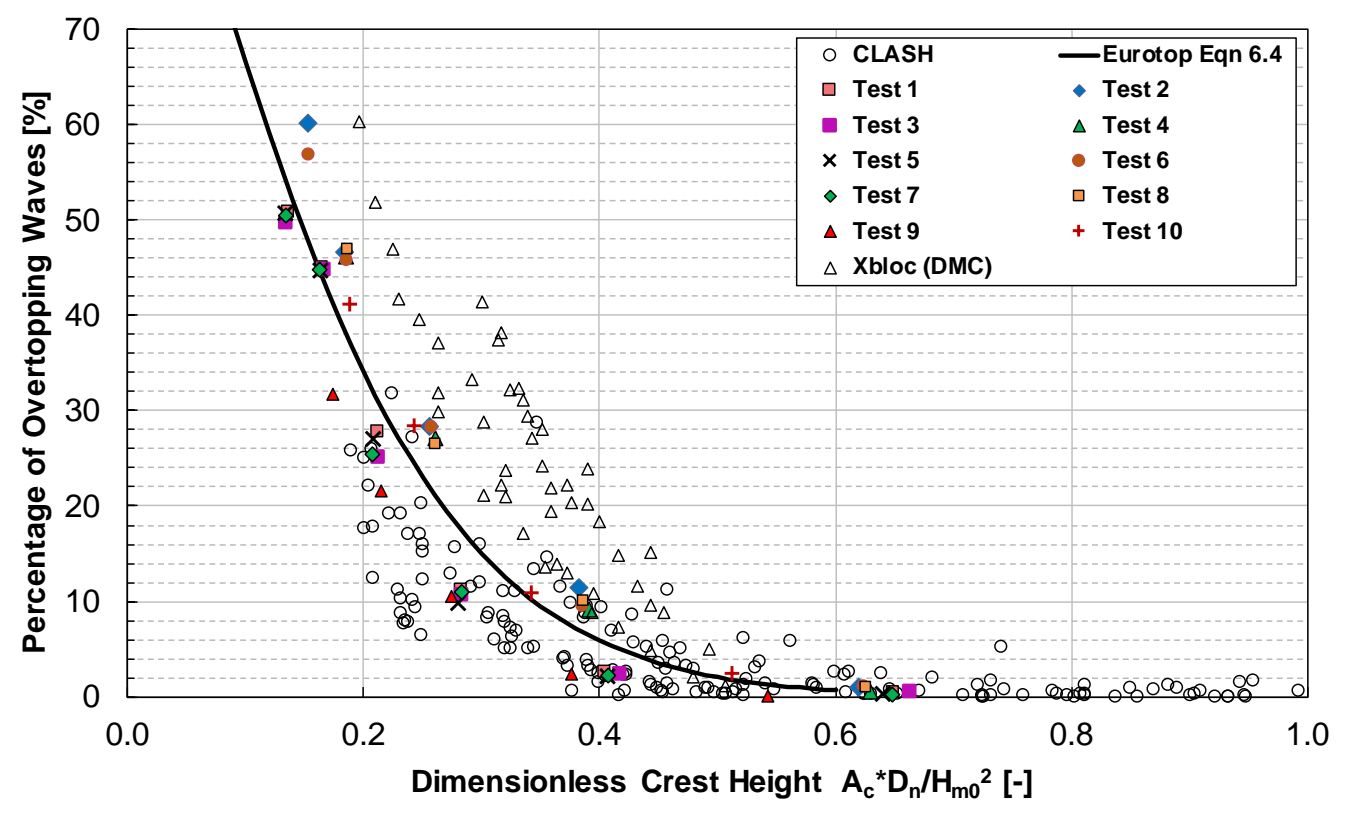

Figure 12: Test results on percentage of overtopping compare to empirical prediction and other single layer units

In Figure 12 the percentage of waves overtopped over the Crablock armour slope in different test series is compared with the results of CLASH (2004) described by Bruce et al. (2009), Xbloc (DMC, 2003) and with the prediction by the empirical formula from EurOtop (2007). From the resulting graph, it can be concluded that for smaller waves the test results are almost within the range of CLASH (2004), more specifically Bruce et al. (2009). It should be noted that the CLASH (2004) data contained a maximum percentage of overtopping around 30\% (EurOtop, 2007). Therefore, the test results on overtopping percentages for higher waves which exceeds $30 \%$ are out of the CLASH (2004) range and cannot be compared. Based on Figure 12 it is also 
observed that in comparison to long waves EurOtop (2007) predicts the percentage of overtopping for short waves well. For example, for tests 2, 4, 6 and 8 (long wave period) EurOtop (2007) underestimates the percentage of overtopping to some extent, while the results of tests1, 3 and 5 (short wave period) are almost on top of EurOtop line.

However, similar to the relative overtopping rate in Figure 10, Figure 12 shows that the overtopping percentage over Xbloc by DMC (2003) is also much higher compared to the empirical prediction by EurOtop (2007), results of CLASH (2004), described by Bruce et al. (2009) and test results of the Crablock.

The difference in results between the measured overtopping over Crablock units, specific CLASH (2004) data on other concrete units and the empirical predictions might be due to the following reasons:

- CLASH (2004) data described by Bruce et al. (2009) are based on 2D experiments which were performed with three wave steepnesses $s_{\text {op }}=0.02 ; 0.035$ and 0.05 . In the present study tests were carried out by using two constant wave steepnesses $\mathrm{s}_{\mathrm{m}-1,0}=0.02$ and $0.04\left(\mathrm{~s}_{\mathrm{op}}=0.015\right.$ and 0.035 ). This means that all the tests with low wave steepness $\mathrm{s}_{\mathrm{op}}=0.015$ were just outside the range of Bruce et al. (2009), which mainly gave higher overtopping compared to those results. For very low steepness there seems to be a trend that a longer wave period gives substantially more overtopping. But this observation should be combined with the remarks on $\mathrm{H}_{\mathrm{m} 0}$ and $\mathrm{H}_{1 / 3}$ below before a firm conclusion can be made.

- All the experiments in the CLASH (2004) project described by Bruce et al. (2009) were performed on a relatively simple standard cross-section without any sloping foreshore in front of the model and with relatively deep water $(0.7 \mathrm{~m})$. However, a sloping foreshore of $10 \mathrm{~m}$ in length with a uniform slope of 1:30 was used in this research. The 1:30 slope changed the shape of the waves and the waves at the structure toe showed a clear increase in velocity (eye observation) of the wave crest (near or at breaking). This might also have been the case for the Xbloc research (DMC, 2003), where also a 1:30 foreshore slope was applied.

- It is worth pointing out that all the empirical formulae on overtopping are based on the spectral significant wave height $\mathrm{H}_{\mathrm{m} 0}$ at the structure. As presented in Figure 10, the dimensionless wave overtopping for CLASH (2004), Xbloc by DMC (2003) and test results on Crablock are also based on $\mathrm{H}_{\mathrm{m} 0}$ at the toe of the structure. However, in the present research it was observed that for the higher wave heights with a long period $\mathrm{H}_{\mathrm{m} 0}$ at the structure considerably differed from $\mathrm{H}_{1 / 3}$ at the structure, see details in Salauddin, 2015. The maximum $\mathrm{H}_{1 / 3} / \mathrm{H}_{\mathrm{m0}}$-ratio for the low steepness become 1.29, which is a very large value. For the higher steepness the maximum ratio was 1.10. Note that this was not the case for the data from Bruce et al. (2009) as it was performed in relatively deep water with respectively short wave periods. Therefore, the use of $\mathrm{H}_{\mathrm{m} 0}$ instead of $\mathrm{H}_{1 / 3}$ also played a role for the difference between Crablock with earlier research and empirical prediction in above figures. To observe the influence of $\mathrm{H}_{1 / 3}$, Figure 11 is re-plotted with the use of $\mathrm{H}_{1 / 3}$ instead of $\mathrm{H}_{\mathrm{m} 0}$, see Figure 13. Based on a comparison of Figures 11 and 13 it can be concluded that by using $\mathrm{H}_{1 / 3}$ the variation between Bruce et al. (2009) and Crablock is considerably reduced. Also, the test results of Crablock units performed 
with two different wave steepnesses have now become much closer to each other. It should be noted that $\mathrm{H}_{1 / 3}$ in the following graph is used only for the comparison, all other analysis of overtopping is performed with $\mathrm{H}_{\mathrm{m} 0}$ at the structure. But above results may raise the question whether using $\mathrm{H}_{\mathrm{m} 0}$ instead of $\mathrm{H}_{1 / 3}$ in overtopping prediction formulae, is a good one.

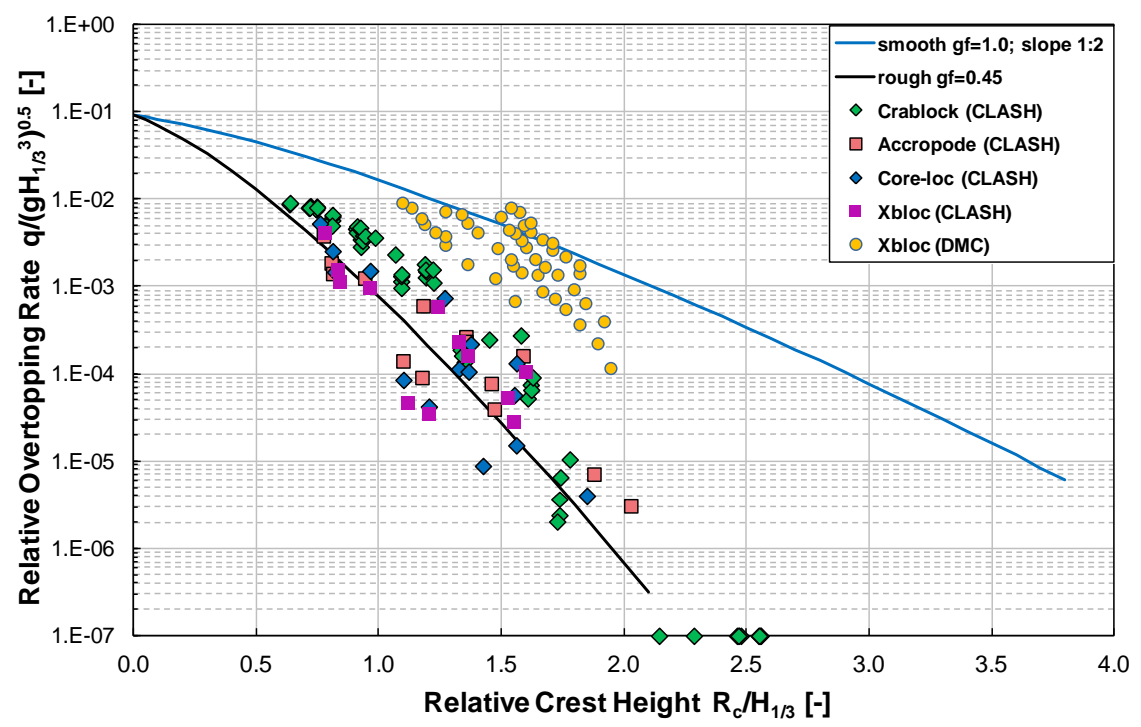

Figure 13: Test results compared to empirical prediction and other monolayer units (using $\mathrm{H}_{1 / 3}$ )

\section{2.3 Pull Tests}

For a packing density co-efficient of 0.63 the results show (Figure 14) an increase in interlocking degree after exposure of waves. The vertical lines express the deviations found and the horizontal lines resemble the average values. For the dry test the ratio Force/Weight can be characterised as in the order of 5 for all three locations, while wave exposure increased this value up to 2-3 times. The difference in results after wave attack between the various locations can be explained by large settlements around the SWL and thus a higher packing density. A higher packing density is assumed to obtain a higher interlocking degree.

In the dry test with a packing density co-efficient of 0.63 no influence of the extraction location was found. The observed packing was so loose that the units above did not contribute to the interlocking degree by providing some additional weight. This is another reason not to allow a packing density co-efficient of 0.63 for a real design.

The ratio between the interlocking degrees with and without wave exposure for a packing density co-efficient of 0.66 is in the order of 3, see Figure 15. In this case, it can also be assumed that settlement increased the packing density and so the interlocking degree. The interlocking degrees found after wave exposure for Location 2 and 3 were almost equal. However, this comparison is based on armour layers exposed to different wave heights. Due to the increase of interlocking degree from Location 1 to 2 it can be assumed that the $\phi=0.66 / \mathrm{D}_{\mathrm{n}}{ }^{2}$ provided enough interlocking thus the weight of the units above was affecting the interlocking degree of units located below. The actual packing density is determined after wave exposure to obtain the relation between interlocking degree, packing density and extraction location. This analysis is 
only done for initial $\phi$ of 0.63 and 0.66 . It is worth mentioning that during test series 1 to 4 the frame to perform the pull tests in the flume after testing, was not ready yet and therefore pull tests were not performed for these tests.

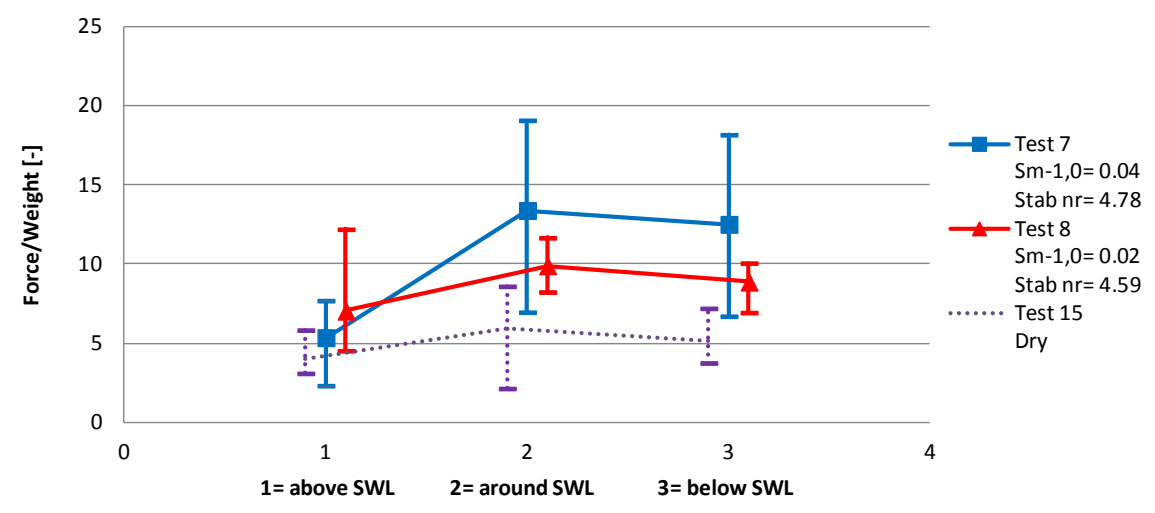

Figure 14: Overview of average interlocking degree for $\phi=0.63$

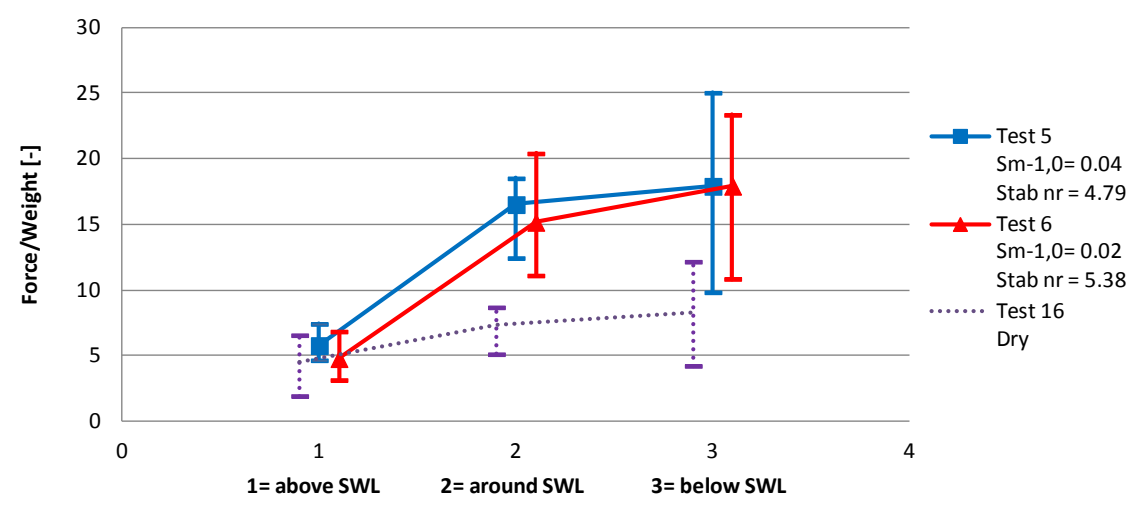

Figure 15: Overview of average interlocking degree for $\phi=0.66$

Figure 16 gives the relation between the packing density and the interlocking degree. For all three extraction locations the interlocking degree becomes higher with an increasing packing density. It is remarkable that not only the packing density plays a role in the interlocking degree but also the extraction location. For the three extraction locations, the ratio between the increase of packing density and interlocking degree is different as the slope of the trend lines differs. The more additional rows above the extraction location, the larger the influence on interlocking degree. Settlement has therefore a significant influence on the interlocking degree. 


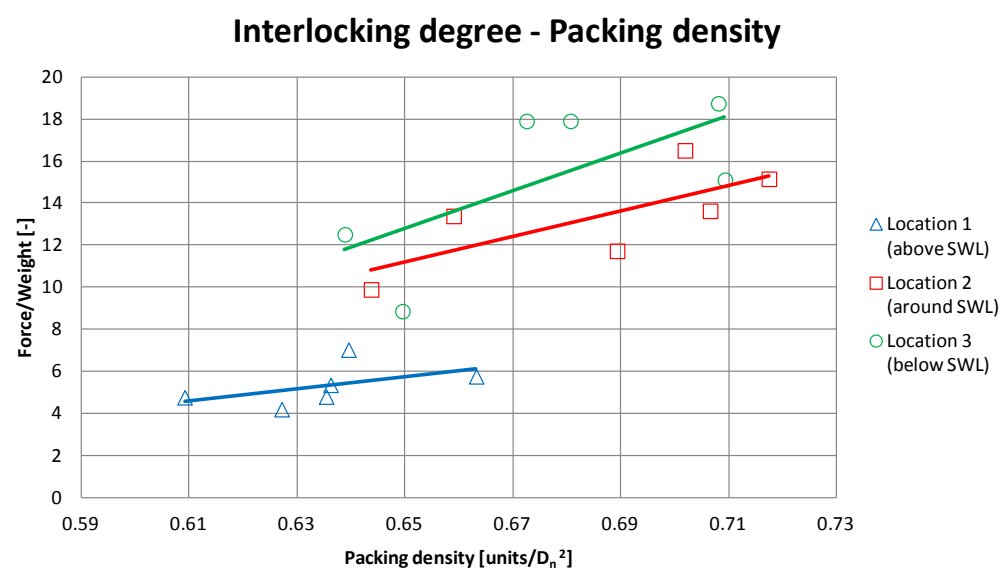

Figure 16: Overview of interlocking degree corresponding to packing density after wave attack

\section{CONCLUSIONS}

Based on the results, analysis and observations, the conclusions of the small scale physical tests on the new symmetrical single layer unit Crablock, can be pointed out as follows:

\section{Placement of Crablock:}

- A proper uniform pattern of Crablock was difficult to obtain in a rectangular grid with a conventional (large) underlayer. The test results showed that a uniform pattern of Crablock can be achieved in a rectangular grid by using a relatively small and smooth underlayer, which is about $1 / 25^{\text {th }}$ of the armour layer weight. This is well within the limits for underlayer stability, but one should realise that a smaller underlayer may give less stability during construction when the armour layer has not yet been placed.

- Regular placement of Crablock was hardly achievable in a diamond-shaped grid. It was noticed that in a diamond shaped grid, a random placement pattern can be achieved with higher accuracy and easily in comparison to a uniform placement pattern.

- For a good interlocked uniform pattern of Crablock armour units on a relatively small underlayer it was possible to obtain the following measured average values:

— Horizontal placement distance: $0.66 \mathrm{D}$ and upslope placement distance: $0.63 \mathrm{D}$ with a packing density coefficient $\phi=0.68$

- It was observed that in a diamond-shaped grid the randomly oriented Crablock units ensure a good interlocked armour with the following measured average values:

— Horizontal placement distance: $0.75 \mathrm{D}$ and upslope placement distance: $0.63 \mathrm{D}$ with a packing density coefficient $\phi=0.61$

Stability:

- Longer waves affected the armour layer more, gave larger and earlier displacements. But this all occurred for very large wave heights exceeding the assumed design wave height significantly (up to 75\%). In realistic conditions this should never occur, of course.

- A high crest level gives large settlements if the design wave height is exceeded significantly.

- The approximated stability number for design is between 2.8 and 3.3. A value of 2.8 is very conservative because this gives a safety factor of about 1.8 with respect to average start of displacements. A value of 3.3 belongs to a safety factor of 1.5, comparable to Xbloc, 
Accropode II and Core-loc, but this value is considerably higher than used for other units and should therefore be chosen with care.

\section{Overtopping:}

- Two different wave steepnesses were tested in this experimental investigation. It was clear that a very low wave steepness (long wave period) gave higher overtopping compared to a high wave steepness (short wave period). This might be due to the 1:30 foreshore slope that had large influence on the wave attenuation at the toe of the structure.

- Overtopping results showed that there is no influence of placement pattern and packing density on wave overtopping.

- The measured relative wave overtopping over Crablock was found to be slightly higher in comparison to CLASH (2004) results on Accropode, Core-loc and Xbloc as described by Bruce et al. (2009). This variation was mainly observed for the test results with low wave steepness with $\mathrm{s}_{\mathrm{m}-1,0}=0.02\left(\mathrm{~s}_{\mathrm{op}}=0.015\right)$, which was slightly outside of the CLASH (2004) range, described by Bruce et al. (2009) with $s_{\mathrm{op}}=0.02 ; 0.035$ and 0.05 . The use of a sloping foreshore (1:30) and a more depth limited situation instead of a horizontal one as in Bruce et al. (2009) might have significant influence on the overtopping behaviour. The 1:30 slope changed the shape and height of the waves and the waves at the structure toe showed a clear increase in velocity of the wave crest (near or at breaking). For the low wave steepness there was a clear difference in wave heights between $\mathrm{H}_{\mathrm{m} 0}$ and $\mathrm{H}_{1 / 3}$ at the structure, almost up to a factor of 1.3 Using $\mathrm{H}_{1 / 3}$ made the differences between test results and predicting formulae much smaller. It may therefore be questioned whether the use of $\mathrm{H}_{\mathrm{m} 0}$ in EurOtop (2007) gives correct results if the values for the two definitions of wave height deviate substantially.

\section{Pull Tests:}

- The results showed no influence of placement pattern on interlocking degree.

- The interlocking degree did not influence the hydraulic stability for packing densities higher than $\phi=0.63$. The interlocking degree was just sufficient and did not result in differences in hydraulic stability.

- Interlocking degree depends more on the number of rows located above the extraction and on increasing packing density by some settlement. The lower placed units have a higher interlocking degree than the higher placed ones for equal packing densities. An increase in packing density, due to some settlement, results for the lower units in a higher increase in interlocking degree. There is a positive influence of the weight of the units above the extraction.

\section{RECOMMENDATIONS FOR DESIGN}

The Crablock is an interesting single layer unit, as it is symmetrical by shape. This means that, in contrast to most other single layer units, a symmetrical placing pattern can be obtained. Some clients like a symmetrical placement more than random placement, see for example the many regular "pitched" rock armour slopes in the Middle East countries. It is for this reason that the unit was chosen for first testing in a wave flume for stability and wave overtopping. The tests are of course not yet conclusive on all possible design aspects. 
The unit is very stable if uniformly placed in a rectangular pattern with sufficient packing density. That is the advantage of the outcome of the tests. But it is not easy to design a rectangular and uniform pattern if the length of the armour slope changes (by depth changes) or if there are curves or breakwater roundheads. A solution has not been found for this design aspect yet.

The stable configuration also needs a quite smooth underlayer, smaller than in many conventional designs. A smaller underlayer is less stable under daily conditions during construction and this may become a disadvantage.

Also, the construction of the first row of Crablock is important. A special toe block design, as available for Xbloc, may be a solution, but this has not yet been designed.

The overall recommendation is that it is worthwhile to explore the disadvantages mentioned above more in depth and to find practical solutions for design.

\section{ACKNOWLEDGEMENTS}

The first author of this paper would like to thank the NICHE-081 BGD project, for funding his MSc study at IHE DELFT. Special thank goes to AM Marine Works and CDR international for partly sponsoring the laboratory studies at Delft University of Technology. Furthermore, we would like to place our appreciations to all the members of the support staff of the Hydraulics Laboratory at TU Delft for their assistance during the experiments. 


\section{REFERENCES}

Bakker, P., Muttray M., Reedijk, B., Van Den Berge, A., Klabbers, M. and Rovers, I., (2003). Development of concrete breakwater armour units. $1^{\text {st }}$ Coastal, Estuary and Offshore Engineering Specially Conference of the Canadian Society for Civil Engineering, New Brunswick, Canada.

Besley, P. and Denechere, M., (2009). Single layer armour systems - toe, crest and roundhead details, Proc. of ICE Conference on Coasts, Marine Structures \& Breakwaters, Edinburgh, ISBN 978-0-7277-4129-5, publn. Thomas Telford, London.

Bonfantini, F., (2014). Set-up to design guidance for the Crablock armour unit. IHE DELFT Institute of Water Education, Delft,Netherlands.

Broere, A. (2015). "Physical model tests on stability and interlocking of new breakwater armour block Crablock." MSc-thesis, Delft University of Technology, The Netherlands.

Bruce, T, Van der Meer, J. W., Franco, L. and Pearson J.M. (2009). Overtopping performance of different armour units for rubble mound breakwaters. Coastal Engineering 56, pp. 166179 DOI http://dx.doi.org/10.1016/j.coastaleng.2008.03.015

CLASH, (2004). Crest Level Assessment of coastal Structures by full scale monitoring, neural network prediction and Hazard analysis on permissible wave overtopping. EC-contract EVK3-CT-2001-00058, www.clash-eu.org.

CLI, (2011a). ACCROPODE ${ }^{\mathrm{TM}}{ }_{\text {Brochure, }}$ http://concretelayer.com/sites/default/files/ACCROPODE\%E2\%84\%A2_Brochure.pdf. Cited 24th September 2014.

CLI, (2011b). THE ACCROPODETM II UNIT 'Technology, experience and cost-effectiveness in a single concrete unit for breakwater armouring', http://concretelayer.com/sites/default/files/ACCROPODE_II_Doc_Incl._Refs_0.pdf. Cited 24th September 2014.

CLI, (2012). CORE-LOC ${ }^{\mathrm{TM}} \_$Brochure, http://concretelayer.com/sites/default/files/CORELOC\%E2\%84\%A2_Brochure.pdf. Cited 24th September 2014.

CSIR, (2009). Crablock Armour Unit 2D Physical Model Study. Built Environment, CSIR, Stellenbosch, Republic of South Africa.

DMC, (2003). Hydraulic Performance of Xbloc armour units -2-D model tests at WL Delft. Delta Marine Consultants, Netherlands.

EurOtop, (2007). EurOtop- Wave Overtopping of Sea Defences and Related Structures: Assessment Manual. UK: Pullen, T Bruce, T NWH Allsop NL: JW van der Meer DE: H Schüttrumpf, A Kortenhaus, http://www.overtopping-manual.com/eurotop.pdf.

Gomez-Martin, M. E. and Medina, J.R., (2006). Damage progression on cube armoured breakwaters. Proc. of the 30th International Conference on Coastal Engineering, ASCE, San Diego, pp. 5229-5240.

Hendrikse, C. and Heijboer, D., (2014). Hydraulic Design Conditions and Marine Structures design Philosophy: The UAE Case. 7th Annual Arabian World Construction Summit, Dubai, UAE 2014.

Jensen, O. J., (2013) Safety of breakwater armour layers with special focus on monolayer armour units, Proc. of the ICE Breakwaters Conference at Edinburgh, ISBN 978-0-7277-5957-7, pp 33-45, ICE publishing, London.

Mansard, E. P. D., Funke, E. R., (1980). The measurement of incident and reflected spectra using a least squares method. Proc. of the $17^{\text {th }}$ International Conference on Coastal Engineering, ASCE, New York, pp. 154-172. 
Medina, J. R. and Gómez-Martín, M. E., 2012. KD and safety factors of concrete armor units. Coastal Engineering Proceedings, 1(33), pp. 29.

Melby, J.A. and Turk, G.F. (1994). The Core-Loc: optimized concrete armor, Coastal Engineering, ICCE, pp. 1426-1438.

Muttray, M., Reedijk, B., Klabbers, M. (2003). Development of an Innovative Breakwater Armour Unit. Coasts and Ports Australasian Conference, New Zealand.

Muttray, M., Reedijk, J., Vos-Rovers, I. and Bakker, P., (2005). Placement and structural strength of $\mathrm{Xbloc}{ }^{\circledR}$ and other single layer armour units. Proc. of Coastlines, Structures and Breakwaters conference 2005, ICE, Thomas Telford Ltd, pp. 556-567.

Muttray, M. and Reedijk, B., (2009). Design of Concrete Armour Layers. Hansa, International Maritime Journal, Vol.146, No. 6, pp. 111-118.

Oever, T. E., (2006). Theoretical and experimental study on the placement of Xbloc. Master of Science, Delft University of Technology.

Phelp, D., Tulsi, K., Abdulla Al Masaood, H. and Eissa, C., (2012). Crablock Concrete Breakwater Armour Unit Development, Modelling and Application in Oman. Proc. of the $8^{\text {th }}$ International Conference On Coastal And Port Engineering in Developing Countries, PIANC - COPEDEC VIII, IIT Madras, Chennai, INDIA, pp. 1727-1737.

Rock Manual, 2007. The Use of Rock in Hydraulic Engineering, 2nd edition. CIRIA, London (CIRIA, CUR, CETMEF, C683, (ISBN 978-0-86017-683-1 and 5)).

Salauddin, Md., (2015). Physical model tests on new armour block Crablock for breakwaters to come to preliminary design guidance. MSc-thesis, IHE DELFT, The Netherlands.

TAW, (2002). Technical Report on Wave Run-up and Wave Overtopping at Dikes. In: Van de meer JW (ed), Technical Advisory Committee on Flood Defence, The Netherlands.

Van der Meer, J.W., (1987). Stability of rubble mound breakwaters. Stability formula for breakwaters armoured with ACCROPODE (R). Delft Hydraulics' Report on basic research H546.

Van der Meer, J. W., (1999). Design of Concrete Armour layers. Proc .of the Coastal Structures '99, Losada edn Balkema, Rotterdam, Santander, Spain, pp. 213-221.

Van der Meer, J.W. and Bruce, T., (2014). New physical insights and design formulas on wave overtopping at sloping and vertical structures. Journal of Waterway, Port, Coastal and Ocean Engineering, vol 140, DOI 10.1061/(ASCE)WW.1943-5460.0000221

Van Gent M. R. A., Spaan G. B. H., Plate S. E., Berendsen E., Van de meer J. W. And d'Angremond K., (1999). Single-layer rubble mound breakwaters. Proc. of the International Conference Coastal Structures, Balkema, Santander, Spain, pp. 231-239. 